\title{
A Comprehensive Review of Bioactive Glass Coatings: State of the Art, Challenges and Future Perspectives
}

\author{
Rachele Sergi, Devis Bellucci and Valeria Cannillo *(B) \\ Dipartimento di Ingegneria Enzo Ferrari, Università degli Studi di Modena e Reggio Emilia, Via P. Vivarelli 10, \\ 41125 Modena, Italy; rachele.sergi@unimore.it (R.S.); devis.bellucci@unimore.it (D.B.) \\ * Correspondence: valeria.cannillo@unimore.it; Tel.: +39-059-2056240
}

Received: 15 July 2020; Accepted: 30 July 2020; Published: 3 August 2020

\begin{abstract}
Bioactive glasses are promising biomaterials for bone and tissue repair and reconstruction, as they were shown to bond to both hard and soft tissues stimulating cells towards a path of regeneration and self-repair. Unfortunately, due to their relatively poor mechanical properties, such as brittleness, low bending strength and fracture toughness, their applications are limited to non-load-bearing implants. However, bioactive glasses can be successfully applied as coatings on the surface of metallic implants to combine the appropriate mechanical properties of metal alloys to bioactivity and biocompatibility of bioactive glasses. In this review, several available coating techniques to coat metal alloys using bioactive glasses are described, with a special focus on thermal spraying, which nowadays is the most used to deposit coatings on metallic implants.
\end{abstract}

Keywords: bioactive glass; coatings; thermal spraying; plasma spraying; enamelling; electrophoretic deposition; sol-gel; thin coatings

\section{Introduction}

Biomaterials have been widely used as implants to replace or repair structural parts of the human body. Implants are traceable to early Egyptians and south-Central American cultures [1]. Improvements in both quality and production processes have been achieved, and make implants very promising for the biomedical field. Depending on the specific biomedical application, implants may have different requirements [2]. In particular, high mechanical strength and fracture toughness make metallic materials suitable for load-bearing components, such as orthopaedic implants, stems, and blood circulatory systems [3]. Metallic biomaterials can be broadly classified as (i) titanium and its alloys (i.e., Ti6Al4V) (ii) stainless steel (i.e., 316L stainless steel), (iii) cobalt-chromium-molybdenum alloys and (iv) precious metal alloys (i.e., gold, silver or platinum based alloys) [2]. Among metallic implants, titanium and its alloys represent the favoured materials for trauma and orthopaedic surgery, because of their low density, high corrosion resistance, and mechanical strength [4]. To be suitable for implant applications, metallic biomaterials should have the Young's Modulus comparable to that of bone to guarantee a more uniform distribution of stress in the implant. Additionally, metallic biomaterials should minimize the relative movement at the interface between implant and bone, to avoid any eventual deterioration of the implant itself or the tissue, or both [5]. Moreover, high tensile and compressive strength, high yield and fatigue strength are all required to improve functionality and prevent brittle fracture under cycling loading. However, despite their great mechanical properties and work efficiency in load-bearing applications, in contact with physiological fluids metallic implants lack in corrosion resistance, bioactivity and osteointegration [6]. The corrosion of metallic implants is critical, because it could negatively affect the mechanical integrity of the implant and its biocompatibility [7], compromising cell metabolism and cell behaviour [8]. Unfortunately, the corrosion of metallic implants cannot be avoided, and oxide films are formed as corrosion products [9]. Oxide films, such as $\mathrm{Cr}$ or Ti oxide, are uniform and dense, 
and they act as protective passive films. However, the scratching and deterioration of sliding parts or load bearing parts is still possible [10], and elevated levels of metals in the bloodstream could lead to several problems such as mental sensitivity, genotoxicity and carcinogenesis [11,12]. To prevent the releasing of metal ions in the bloodstream and to improve bioactivity and osseointegration of metallic implants, biological active materials, such as ceramics, glass-ceramics and bioactive glasses have been widely used to coat metallic implants [13]. Bioactive coatings allow prostheses to adapt to bone cavity preventing the formation of fibrous tissue at the interface between implant and bone; thus, inflammation, irritation and tissue damage can be prevented [8].

Additionally, bioactive coated implants have a higher integration rate, promote faster bone attachment and achieve higher attachment strength to bone, compared to non-coated metallic implants $[14,15]$. Therefore, bioactive coatings (i) avoid the corrosion and degradation of metallic implants, (ii) protect surrounding tissues from adverse interaction with degradation products of metallic implants, and (iii) enhance bioactive fixation of implants to the living bone promoting osseointegration. In this context, the principal requirement for bioactive coatings is the achievement of strong adhesion to the substrate, because such adhesion determines the long-term stability of the implant $[16,17]$. Thus, metallic implants coated by bioactive coatings combine the good mechanical properties of metals or alloys with bioactivity, biocompatibility and corrosion resistance of ceramics, glass-ceramics and bioactive glasses $[14,18,19]$. Among bioactive coatings for metallic implants, hydroxyapatite (HA) is one of the most widely employed [20-23], and the plasma spraying technique is the most used to obtain HA coatings on titanium and titanium alloys; the femoral stem is still the major application for HA coatings. HA has been widely applied because of its resemblance to the inorganic phase of natural bone tissue and results promising for osseointegration [24,25]. However, the stability of HA-based prosthesis depends on the degree of crystallinity of HA and its chemical composition; highly crystalline HA is almost stable, but poorly crystallised HA undergoes quite fast degradation [26]. In fact, HA coatings revealed frequent delamination and inadequate chemical stability, which compromised the long-term success of implants $[27,28]$. Thus, even if alternative solutions such as functionally graded coatings have been proposed $[29,30]$, the chemical instability of HA and its relatively low bioactivity drive research to find different bioactive materials to coat metallic implants.

The highest degree of bioactivity and the possibility to be produced by varying their chemical composition by adding secondary elements [4] make bioactive glass coatings particularly attractive as an alternative to HA coatings. Furthermore, all bioactive glasses bind to bone and some bind to soft tissue too; the connection between bone and bioactive glass coatings reach a force comparable to that of bone, 3-6 months after implantation [31]. Moreover, bioactive glasses are, by nature, biodegradable showing different dissolution rates depending on the specific bioactive glass composition and on the $\mathrm{pH}$ of the surrounding environment. Although the faster dissolution rate of bioactive glasses enhances bone growth by hydroxy-carbonate apatite (HCA) formation, the fabrication of bioactive glass coatings on complex 3D structures is still a great challenge. Microstructure, thickness, surface roughness, porosity, as well as the stability, will dictate the performance of bioactive glass coatings.

Bioactive glasses are not as new as biomaterials; since the development of $45 \mathrm{~S} 5$ by L.L. Hench in the late 1960s, various bioactive glass compositions have been developed. Bioactive glasses can be categorized as silicate-based, borate-based and phosphate-based [32]. Phosphate-based and borate-based bioactive glasses show a high dissolution rate, being suitable for healing applications [33]. On the other hand, silicate-based bioactive glasses are the main category of glasses showing bioactive behaviour, and employed in clinical applications.

Various surface modification technologies have been developed and employed to coat metallic implants, including thermal spraying [34], sol-gel, chemical and electrochemical treatment, such as electrophoretic deposition [35]. Unfortunately, some of these technologies show drawbacks, such as poor bonding strength between implants and coatings, the induction of phase transformation, modifications in the properties of coating or metallic implant, or both, and presence of impurities. 
This paper expands and updates our previous review [36], analysing the most important coating techniques and going through advantages and disadvantages of each.

Figure 1 schematises the principal techniques described in the paper.

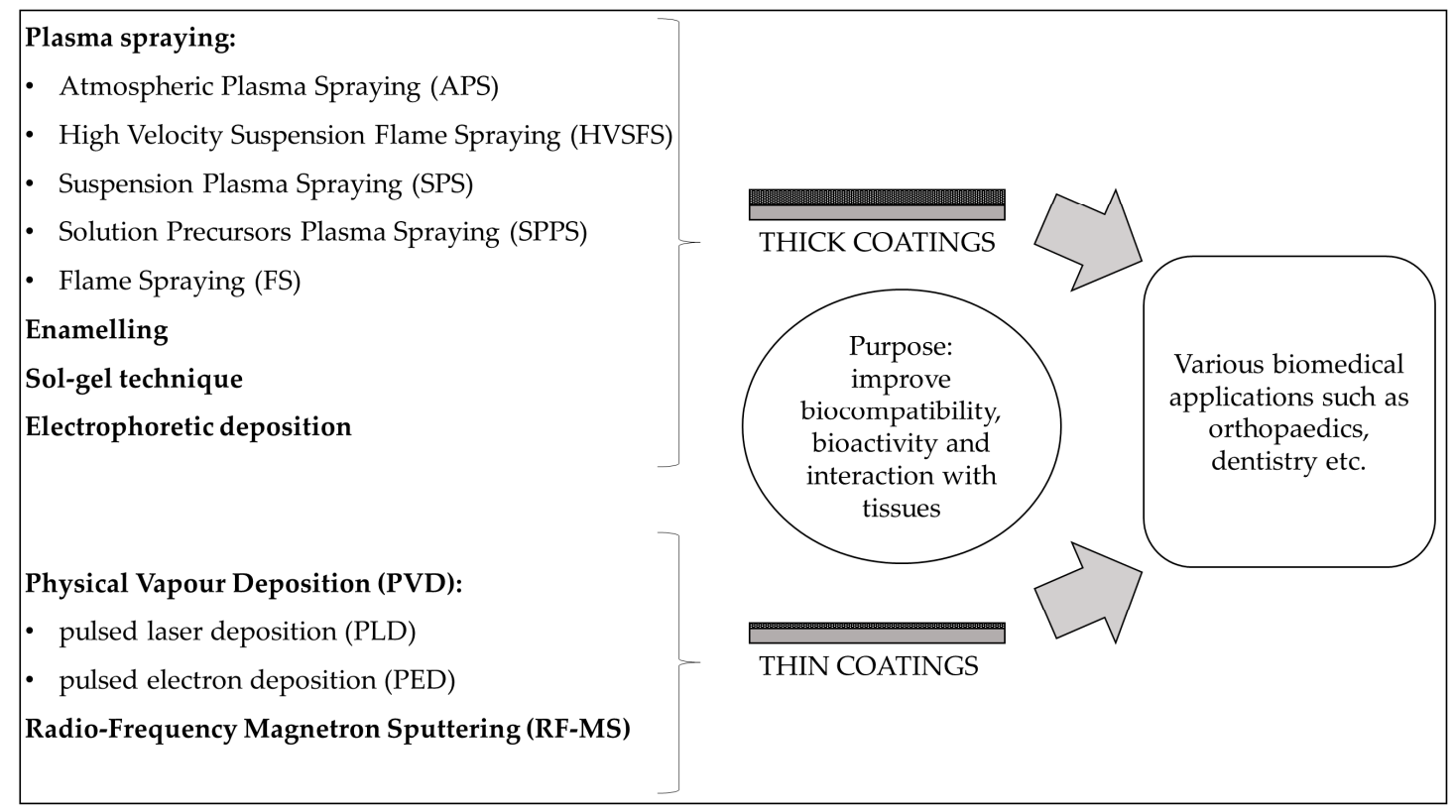

Figure 1. Principal techniques for bioactive glass coatings.

\section{Coatings Deposition Techniques}

\subsection{Thermal Spraying}

Thermal spraying is a well-established technology commonly used to produce coatings, for a wide variety of applications. This technique is a continuous melt-spray process, in which particles are melted and accelerated to a high velocity, through either a combustion flame or a cold flame. Thermal spraying processes can be categorised on the basis of different energy sources used to heat, to a softened or molten state, the coating material (i.e., feedstock) during spraying, namely kinetic energy (cold spraying low/high pressure), chemical energy (flame spraying (FS), high velocity oxygen fuel (HVOF), high velocity air fuel (HVAF), detonation gun (D-gun)), and electric energy (plasma spraying such as atmospheric plasma spraying (APS), suspension plasma spraying (SPS), solution precursor plasma spraying (SPPS), vacuum plasma spraying, wire arc spraying, plasma radio frequency, shroud plasma spraying) $[37,38]$.

Among the different coating techniques, thermal spray techniques have been widely used to develop bioactive glass or glass-ceramics coatings on metal substrates $[39,40]$. Through this technique, the coating can be chemically and structurally controlled, and it can be deposited on different implant shapes [41,42]. The molten and semi-molten droplets impinge the substrate and rapidly solidify to form splat particles. The coating is built up by successive deposition and bonding of splats over the already deposited ones. The splats accumulate into a well bonded deposit, generally $>10 \mu \mathrm{m}$ thick, resulting from the impact, spreading and rapid solidification of flame melted-particles [43]. The microstructure of the coating and its properties depend on the feedstock and processing parameters [43]. Thermal plasma spraying, using a mixture of gases (i.e., argon/hydrogen) and elevated temperature (thousands of degrees ${ }^{\circ} \mathrm{C}$ ), permits one to obtain coatings on a substrate by injecting feedstock powder into the plasma. The feedstock is injected into the hottest part of the plasma flame, to be immediately melted and deposited onto the substrate, where it undergoes rapid solidification. The firing cycle should degrade neither bioactive coatings, nor metallic implants. Some drawbacks of plasma spraying are its high cost and the possible crystallization of bioactive glass during spraying. In fact, the amorphous nature of 
bioactive glasses is one of the principal characteristics that have to be governed and preserved during a thermal spraying process. Crystallization of bioactive glass prior to appreciable densification should be avoided, because it could limit the final density of the coating [43], and could modify the bioactivity and chemical behaviour, because of the new phases in the coatings [32,44-46]. Poor interfacial bonding, thermal stresses, incompatible interfacial reaction and deterioration of glass and/or metallic implants at sintering temperature could limit the ability to develop bioactive glass coatings with the required combination of properties. To avoid thermal stresses into the coating, bioactive glasses with slightly lower thermal expansion coefficient than the implant [47] have been developed, by (i) increasing the silica content at the expense of bioactivity, (ii) adding different oxides such as $\mathrm{MgO}, \mathrm{K}_{2} \mathrm{O}$ [48]. Moreover, particles sizes, volume densities, morphologies and sometimes particles orientations influence elastic moduli, fracture strengths, and thermal conductivity of final coatings [43]. Another limiting factor is the difficulty to obtain a well adherent coating [49]. However, plasma spray presents high deposition speed, good control of the substrate degradation, and it makes it possible to control the thickness, morphology, and structure of the coating by adjusting deposition parameters [13]. An adequate control of processing conditions is pivotal for the fabrication of reliable and successful coatings. The final properties of bioactive glass coatings depend not only on the kinetic and thermal energy involved during spraying process, but on cohesive strength between splats, size and morphologies of pores and the occurrence of cracks and imperfections [43]. Different thermal spraying methods are presently employed to deposit bioactive glass coatings on metallic implants: atmospheric plasma spray (APS), vacuum plasma spray (VPS), high velocity suspension flame spraying (HVSFS), suspension plasma spraying (SPS), solution precursor plasma spraying (SPPS), flame spraying (FS), cold spray, etc. [37].

The atmospheric plasma spraying (APS) consists of a torch set up with a tungsten cathode and a copper anode. The electric arc discharge supported by a generator through the connectors heats the working gases, forming a jet [37]. The gases $\left(\mathrm{N}_{2}, \mathrm{Ar}, \mathrm{H}_{2}, \mathrm{He}\right)$ are ionized by electrical energy when they pass through the high energy electrical arc formed inside the torch. The temperature of a plasma in a typical plasma torch is thousands of degrees [37,50]. The powder suspended in a carrier gas is injected into the jet. The particles of the powder are melted and accelerated to impinge the substrate forming the coating [37]. Generally, the APS technique is used to spray hydroxyapatite coatings; however, this technique can be employed to spray bioactive glass coatings after the optimization of parameters. Type and ratio of gases, flow rate, plasma arc, torch-substrate distance need to be optimized to preserve the typical amorphous nature of bioactive glasses [45]. For instance, partial or total crystallization could occur by increasing the distance between the torch and the substrate, because bioactive glass particles spend more time into the plasma flame before hitting the substrate [49]. However, the stability of the amorphous phase depends principally on the chemical composition of the bioactive glass, which determines the glass forming stability (GFA, the capacity of the liquid material to form an amorphous phase upon cooling). Furthermore, $\mathrm{MgO}$ containing bioactive glasses has been developed to increase the resistance of bioactive glass to crystallization [51]. The resistance of bioactive glass to crystallization during heating increase with $K_{\mathrm{H}}$ parameter, which is the Hruby parameter calculated through the following equation [51]:

$$
K_{\mathrm{H}}=\frac{T_{\mathrm{c}}-T_{\mathrm{g}}}{T_{\mathrm{m}}-T_{\mathrm{p}}}
$$

where $T_{\mathrm{g}}, T_{\mathrm{c}}, T_{\mathrm{p}}$ and $T_{\mathrm{m}}$ are the glass transition, onset of crystallisation, crystallisation peak, and melting temperatures, respectively. The higher resistance to crystallization of $\mathrm{MgO}$ containing bioactive glass is confirmed by the work of Monsalve et al. [51], in which a bioactive glass coating obtained from bioactive glass with $2 \mathrm{wt} . \% \mathrm{MgO}$ showed less-intense peaks of crystalline phase than those of a coating obtained from a bioactive glass with $0 \mathrm{wt} . \% \mathrm{MgO}$ content. However, both coatings deposited from 0 and $2 \mathrm{wt} . \% \mathrm{MgO}$ containing bioactive glasses were prevalently amorphous. The amorphous phase in the coatings was higher than in bioactive glass powders after heating, because of the faster cooling of melted particles on the substrate which decreases the mobility of atoms before they can pack into 
a thermodynamically favourable crystalline state [52]. The introduction of $\mathrm{MgO}$ oxide seems not to affect the bioactivity of coatings, which showed hydroxy-carbonate apatite (HCA) one day after immersion in simulated body fluid (SBF), a solution with an ion concentration close to that of human blood plasma. The intensity of characteristic peaks of HCA (i.e., $\mathrm{P}-\mathrm{O}$ symmetric stretching in $\mathrm{PO}_{4}{ }^{3-}$ ) increases with increasing immersion time in SBF, as detected by means of XRD and Raman analysis. Despite the high resistance to crystallization and good bioactivity, these coatings showed less adhesion strength compared to that measured for coatings deposited using $45 \mathrm{~S} 5$ on titanium [53]. The same results on poor and not homogenous adhesion were found by Gabbi et al. [39], who employed MgO and $\mathrm{Al}_{2} \mathrm{O}_{3}$ containing bioactive glass to develop coatings on titanium alloy (Ti6Al4V). Less adhesion on the substrate suggests that the plasma spraying process did not provide a continuous structurally compacted coating, and that the bioactive glass could undergo compositional modification during spraying. However, XRD analysis confirmed the amorphous nature of coatings, and both in vitro and in vivo results showed an increase in protein activity inside cells, the absence of fibrous tissues and new osteogenesis. Therefore, bioactive glass coatings preserving the amorphous nature of the glass showed an improved bioactivity response [54], cell adhesion in vitro and osteointegration in vivo. Bioactivity depends on the bioactive glass composition, which in turn determines its dissolution. Specific ions release may be relevant for a biological process, but a too fast dissolution of bioactive glass network is not desirable, also because it can lead to abrupt $\mathrm{pH}$ changes or to high $\mathrm{pH}$ values in the surrounding biological fluids. Therefore, $\mathrm{Al}_{2} \mathrm{O}_{3}$ has been added, to increase the durability with respect to leaching and to stabilize the coating for up to 6 months [55]. Aluminium reduces the bioglass dissolution by the formation of a silica-alumina-rich film [55]. A high resistance to crystallization and proper rate of dissolution are not the only desirable features to obtain successful bioactive glass coatings; the morphology and particles size of bioactive glass influence the kinetic energy, the flowability of feedstock and the microstructure of the final coating as well. The particle size of bioactive glass powders should allow sufficiently melt and adhesion on substrates during splats deposition to build up the coatings. If the particle size is too fine, the flowability inside the plasma flame decreases because the pneumatic transport of powders from the container to the torch results in being difficult or impossible. The decrease in the flowability of particles is due to the frictional forces between particles when the particles size of powder is reduced. In fact, when the particle size of powders becomes increasingly smaller, the adhesion force between particles overcomes the gravity forces, which predominate for coarse particles [34]. Finer particles showed evident hygroscopic behaviour, with a reduced flowability [56,57]. Cañas et al. [34] studied the effect of the flowability of particles, and the capacity to obtain bioactive glass coatings. Coarser $(>200 \mu \mathrm{m})$ and finer $(<63 \mu \mathrm{m})$ powder fractions gave no rise to coatings, because the particles of the coarse fraction could not properly melt to form splats on the substrates, and the finer particles showed a high ability to absorb water [34]. To reduce the hygroscopic behaviour of fine particles, hygroscopic fluidiser could be added to initial feedstock before spraying. Melt and semi-melt particles were observed, and the amorphous nature of bioactive glass was maintained after spraying as confirmed by means of XRD analysis [34]. Anyway, as mentioned, the size of particles is not the only feature of feedstock that influences and determines the obtainment of a well-deposited coating; in fact, the morphology of feedstock influences the coating microstructure as well. Spherical bioactive glass particles form less dense coatings compared to irregular particles, which form denser and homogeneous coatings, as shown by Calvo et al. [58]. Coatings characterized by heterogeneous microstructure made up of large round pores inside splats were developed using spray-dried agglomerate feedstock, which was characterized by spherical particles with high porosity [59]. During the travel of particles from the torch to the substrate, the surface of spray-dried agglomerates melts, but not their core [60]. Thus, when spray-dried agglomerates hit the substrates, the splats exhibit limited deformation capability because of the low melting degree of feedstock. On the other hand, irregular particles, which exhibit angular and typical shape of ground frit particles, showed the capability to build up homogeneous coatings if the particles were finer [58]. Therefore, a homogenous microstructure composed by a well 
molten matrix containing rounds pores was obtained using irregular fine particles as feedstock. Even if the microstructure showed pores, they were smaller and less numerous compared to pores obtained using spherical agglomerate or coarse irregular particles. Finer particles decrease the temperature gradient during the splat cooling on the substrate, resulting in less thermal stresses with less cracks [58]. Furthermore, hydroxy-carbonate apatite (HCA) appears at a shorter time, on coatings deposited from fine particles, compared to that deposited from coarse or spherical particles $[26,58,61]$. However, it is worth noting that the formation of HCA film on the surface of bioactive glass coatings in vitro represent an easy but not sufficient evaluation of bioactive glass coatings biocompatibility in vivo [40].

Since the bioactivity index and the dissolution rate of 4555 are higher than those of hydroxyapatite [62], an approach to obtain bioactive coatings with desired properties is to combine hydroxyapatite and bioactive glasses $[63,64]$. The aim is to obtain a desired resorption rate, and to maintain a high adhesion to the metallic substrate thanks to hydroxyapatite. For this reason, $45 \mathrm{~S} 5$ was combined with hydroxyapatite, to tailor the dissolution rate and to increase the in vitro bioactivity of coatings [63].

Since $45 \mathrm{~S} 5$ and bioactive glasses are more reactive and require less time to bond with bones in vivo, they are promising for orthopaedic implants in substitution of hydroxyapatite coatings. The Ca-P rich layer in vivo was believed to correspond to the apatite structure observed in vitro on $45 \mathrm{~S} 5$ coatings; as a matter of fact, the Ca-P rich layer is an important index of biocompatibility [65]. Furthermore, Newman et al. [66] demonstrated in vivo that it is possible to increase early bone formation by using a Sr-containing bioactive glass (SrBG) to coat implants, compared to HA-coated implants. SrBG has benefits in the field of skeletal reconstructive surgery, compared to the gold standard treatment in orthopaedic surgery [66].

In conclusion, bioactive glass coatings obtained by APS showed advantages in terms of bioactivity and biocompatibility compared to ceramic coatings such as hydroxyapatite. However, plasma spray parameters and morphology of particles need to be optimized to obtain homogenous coatings, preserving the amorphous nature of bioactive glass feedstock.

Even though APS technique remains the most used to develop coatings on metallic implants, in the last few years, the attention has turned toward thermal spray techniques which allow one to obtain thinner and homogenous bioactive glass coatings, such as vacuum plasma spray (VPS), suspension plasma spraying (SPS), solution precursor plasma spraying (SPPS) and high velocity suspension flame spraying (HVSFS).

Vacuum plasma spraying (VPS) has a similar functional principle to APS, but it is conducted under vacuum chamber. This allows to obtain high quality coatings with low or null oxidation, because the interaction with oxygen during spraying is limited [37].

On the other hand, the solution/suspension precursor plasma spraying, such as high velocity suspension flame spraying (HVSFS), suspension plasma spraying (SPS) and solution precursor plasma spraying (SPPS) permits one to obtain thin coatings without directly handling small powders. The suspension or solution of fine particles allow one to overcome uncontrolled agglomeration and the difficult penetration into plasma jet of fine particles [67]. Bioactive glass particles are dispersed into a solvent, which will be sprayed over substrates to deposit bioactive glass coatings. Bioactive glass particles should be well dispersed into the solvent, to avoid the formation of agglomerates which could compromise the spraying process [68]. Furthermore, the solid phase should not precipitate during storage and spraying processes [67]. The solvent and bioactive glass feedstock must be stable for the suitable suspension ready to be sprayed. To stabilize the suspension some deflocculant agent or dispersant could be added. These additives lead to the electrostatic and steric stabilization of the liquid feedstock [69]. The viscosity of liquid feedstock determines its facility to be pumped and transported in a pipeline to the torch. The particles increase the viscosity of suspension/solution [70]; well dispersed and stable suspensions have low viscosity. To have a successful coating deposition, liquid feedstock should penetrate the hot temperature central zone of the flame. Axial injection and high velocity combustion torch [71] achieve the central injection of liquid feedstock, whereas torches with radial injections need optimization to spray liquid feedstock. Despite the use of liquid feedstock, 
the above mentioned processes employ the conventional thermal spray equipment; for these reasons, it is possible to include these processes in the family of thermal spraying processes [67].

Among the processes that use liquid feedstock, high velocity suspension flame spraying (HVSFS) uses a mixture of fuel and oxygen in a combustion chamber. This technique uses the free expansion of a compressed flame via a converging nozzle at the end of the torch, generating a supersonic jet. The oxygen and fuel gas generate high pressure flame [4], which melts or partially melts the materials used as feedstock. The advantages of HVSFS over other thermal spray techniques is the high velocity of feedstock (i.e., bioactive glass particles), and the relatively low flame temperature, which allow the deposition of thin, dense, and finely structured layers, with nanometric or submicrometric particles and nanometric porosity for maximum specific surface area [72]. These bioactive glass coatings showed superior mechanical properties and lower coating thickness compared to those of atmospheric plasma spraying [73]. Additionally, the problems of flowability of fine dry powders during conventional spraying can be overcome by using liquid suspension as feedstock. When a suspension stream is injected inside the gas jet: (i) the stream is fragmented into small particles (i.e., droplets); (ii) the solvent evaporates and (iii) agglomerates or individual particles are released impacting the substrate [74] to build up the coating. The agglomerates could show a hollow morphology when the solvent evaporates rapidly from the droplets $[67,75]$. Most of the large agglomerates and coarse particles are heated only on their outer surface, while their core remains at low temperature during the limited time inside the gas jet. This behaviour is typical of glasses [76]. On the other hand, small agglomerates and fine particles can be completely heated, but due to their low inertia and low heat capacity [77], their temperature and velocity decrease before they can hit the substrate. The relatively low impact speed and low temperature of small agglomerates and fine particles, together with the cooling effect by the substrate, can cause the freezing of particles before they can properly spread. This could explain the presence of fine non-flattened droplets in the layer directly in contact with the substrate. However, the subsequent layer is deposited on the previous glass layer, which is warmer than the substrate. This allows the particles of the second layer to cool down slowly, having time to spread and adhere on the bioactive glass layer already deposited. In fact, the glass droplets quench more rapidly when directly impacting the metal substrate compared to those depositing on warm pre-deposited glass layers. Consequently, some might not adhere properly and rebound, or fall off [78]. For these reasons, coatings deposited during subsequent torch cycles are characterized by layers with different thickness and porosity [74,78-80]. Even though some bioactive glasses with a low tendency to uncontrolled devitrification with high in vitro bioactivity were successfully deposited [80-82], the interlayer porosity cannot be easily overcome, and seems to be an intrinsic phenomenon during HVSFS processes of silica based glasses [74]. However, the use of bioactive glasses with low tendency to devitrification allows the preservation of amorphous phase of coatings with few cracks. The good homogeneity and few cracks of coatings are an indication of the strong bonding of glass-metal interface [83]. For example, the group of Cannillo et al. [80-82] showed that a potassium based bioactive glass had very promising characteristics in terms of low tendency to uncontrolled devitrification and high in vitro bioactivity, thus being suitable for thermal treatment.

On the other hand, suspension plasma spraying (SPS), which still employs liquid feedstock, is more versatile and flexible compared to HVSFS and it does not show the risk to build up crusts of material on the inside of the torch [84]. Due to its flexibility, the SPS technique has already been proposed for a large variety of functional applications, such as solid oxide fuel cells [85], thermal barrier coatings [86], and it has been considered for the deposition of bioactive glass coatings [84]. Moreover, in this case, the use of liquid feedstock allows spraying finer particles compared to that sprayed by conventional plasma spraying process. However, it should be considered that fine and small particles reach the appropriate velocity and temperature of deposition in the plasma jet core only. In fact, small particles can impact laterally the substrate if they follow the gas flow streamlines developed parallel to the surface of the substrate; in this way, peaks which increase the roughness of the surface were formed [87]. Therefore, the liquid must be injected as close as possible to the torch nozzle, 
to ensure that most of the injected liquid reaches the plasma jet core with very little fragmentation in plasma plume and plasma fringe. In the SPS process, the particles undergo a different pathway compared to that during conventional plasma spraying. During spraying, droplets into suspension undergo (i) aerodynamic breakup; (ii) evaporation of liquid; (iii) sintering of fine solids; (iv) melting of sintered agglomerates and of fine solids; (v) evaporation of liquid material; and (vi) impact with the substrate [67]. The aerodynamic breakup consists of the disintegration of large droplets into a smaller one and occurs shortly after the injection of large droplets [52]. Then, the evaporation of liquid leads to a rapidly decrease of the diameter of droplets. The shape of agglomerates mimics a bulk or a hollow sphere depending on evaporation speed [75]. After the evaporation of liquid, the sintering process starts, and the driving forces of solid-state sintering are the decreasing of surface area and the decreasing of free energy by the elimination of solid vapour interfaces. Subsequently, fine and coarse particles undergo melting, and follow the same step as in dry-spraying process. For these reasons, the characteristic of feedstock strongly affects the liquid phase sintering of the as-sprayed bioactive glass particles. Furthermore, the microstructural features of coatings depend on the size distribution of particles, sedimentation rate, viscosity and selection of solvent [34]. The low viscosity and the reduced modification of viscosity with time are the key requirements for the suspension feedstock in SPS processes [88]. Therefore, sedimentation and rheological tests were performed on suspensions, with or without the addition of dispersants, to select the suspension that prevented agglomeration and sedimentation [68]. The amount of particles which can be added to the suspension (maximum $20 \mathrm{wt} . \%$ ) represents a limitation of deposition efficiency of the SPS process compared to the conventional plasma spraying process [87]. The deposition efficacy is also influenced by the spraying distance [61]; the optimization of the spraying distance permits to have a top zone formed by melted and agglomerated particles, which result in a flat and dense area. A gradual heating of the system occurs with each torch run, resulting in a coating temperature higher than that of $T_{\mathrm{g}}$ of the bioactive glass. Hence, a viscous glass coating is formed on the first glass layer deposited, on which particles can easily stick resulting in a dense and homogeneous top zone [89].

Since few papers on this topic are reported, the study of Cañas et al. [68] was focused on the preparation process to obtain a stable suspension, using $47.6 \mathrm{SiO}_{2}, 5.3 \mathrm{P}_{2} \mathrm{O}_{5}, 23.1 \mathrm{CaO}$ and $24.0 \mathrm{Na}_{2} \mathrm{O}$ (in oxide wt.\%) as bioactive glass particles and dipropylene glycol methyl ether as organic solvent with a portion of $10 \mathrm{vol} . \%$ of solids and $90 \mathrm{vol} . \%$ of solvent. Sedimentation and rheological tests were performed on the suspensions, with the addition of various dispersants at different proportions to select the suspension that prevented agglomeration and sedimentation. A second milling step in wet condition was necessary to obtain suspensions with much finer particles, with viscosity and thixotropic cycle being very low. In fact, the low viscosity is one of the key requirements for the suspension feedstock in a SPS process [88]. Although the preliminary coatings maintained the amorphous nature of feedstock, their microstructure was characterized by cracks and micropores [68]. However, these results allowed one to conclude that the processing conditions and the dispersing materials were adequate to prepare bioactive glass suspension feedstock to be used in the SPS process. Following this preliminary study on the optimization of suspensions containing bioactive glass particles, Cañas et al. [89] developed bioactive glass coatings by SPS, using the same glass. Furthermore, the SPS technique was also successfully employed to design bioactive glass/hydroxyapatite (HA) functionally graded coatings [26,61,90,91]. The graded coatings were characterized by a gradual changing composition, starting from hydroxyapatite at the interface with the metal substrate, up to pure bioactive glass on the surface. Such graded coatings combined a good biocompatibility with a strong adhesion to the substrate [91]. The coating adhesion was preserved even after in vitro tests, thanks to the presence of the stable hydroxyapatite at the interface with the substrate [26,91]. Additionally, bioactive glass on the surface, as well as bioactive glass topcoat, showed a greater reactivity with respect to pure hydroxyapatite coatings in SBF [26,61,90,91].

Another promising technique is the solution precursor plasma spraying (SPPS). SPPS yields to high purity feedstock compared to HVSFS and SPS, because such a technique avoids traditional processing steps such as melting, quenching, milling, drying etc., which can insert contaminant into 
feedstock. SPPS permits to spray thin coatings, even nanostructured, with a highly homogeneous microstructure $[66,67,92,93]$. The phenomena occurring during solution spraying involve the precipitation of solute, and are different from the phenomena occurring during SPS processes. Droplets into solution undergo (i) aerodynamic breakup; (ii) heating, vaporization and internal precipitation; (iii) internal pressurization and droplet breaking-up; (iv) solid particle heating and melting; (v) evaporation from the melt; and (vi) impact with the substrate [67]. After aerodynamic breakup particles undergo rapid vaporization of solvent; the concentration of solute on the droplets surface increases until the level of supersaturation is reached. Then, the precipitation of solid shells is due to the concentration of solute [94], and different routes are possible. Volume precipitation and uniform concentration of solute lead to the formation of solid particles; super-saturation near the surface of the droplets lead to the formation of inelastic shells or elastic shells [67].

At the moment, there are just a few studies regarding SPPS with bioactive glass precursors. $45 \mathrm{~S} 5$ bioactive glass coatings were deposited by SPPS on AISI304 stainless steel (with $\mathrm{TiO}_{2}$ bond coat) by Cañas et al. [93] By varying the argon flow rate and the spraying distance different morphologies of coatings were obtained [93]. Better coatings were obtained with short spraying distance and high plasma torch enthalpy. The high enthalpy contributes to the development of the different physical processes occurring during flight (i.e., evaporation, gelation, pyrolysis, sintering and melting of bioactive glass particles [95]). Furthermore, the high spraying distance allowed some of glass molten particles to re-solidify and crystallize during flight $[95,96]$. On the other hand, by using short spraying distance and argon flow rate of $25 \mathrm{slmp}$, denser and homogeneous coatings were deposited [97]. Two different zones typical of liquid feedstock deposition could be identified: a first layer of fine bioactive glass rounded drops and a top layer of larger bioactive glass agglomerates were obtained [68,97]. The inner surface was more bioactive than the agglomerates on the top zone; anyway, the interconnected porosity of coatings favoured the bioactivity of the bioactive glass surface. These results open new research opportunities concerning feedstock stability and microstructure optimization in the SPPS process, as well as further improvement in coatings' adherence, and in the elimination of the crystalline phase.

Another technique is flame spraying (FS), which is economic and simple compared to other techniques mentioned before. FS relies on combustion of an oxygen fuel flame to melt feedstock powders, allowing the obtainment of porous coatings and composite coatings. Monsalve et al. [98] deposited $31 \mathrm{SiO}_{2}-11 \mathrm{P}_{2} \mathrm{O}_{5}-(58-x) \mathrm{CaO}-x \mathrm{MgO}$ bioactive glass coatings on AISI $316 \mathrm{~L}$ and Ti6Al4V substrates. The crystallinity of coatings decreased with increasing content of $\mathrm{MgO}$, owing to the depletion in $\mathrm{CaO}$, which promotes crystallization. Moreover, the crystallization of the coatings was higher on Ti6Al4V substrates compared to AISI 316L substrates; the lower thermal conductivity of Ti6Al4V caused a decrease in the cooling rate, allowing the formation of some crystalline phases. The bioactivity was confirmed by the formation of a hydroxycarbonate apatite (HCA) layer, after immersion in SBF solution.

Finally, it is worth mentioning, among non-traditional thermal spray processes, cold spraying [43]. The cold spraying technique does not use thermal energy. The formation of coatings from droplet particles that solidify during flight from thermal sources (torch) to the substrate has been described as hypervelocity impact fusion [52,99]. Cold spray deposits are developed in the absence of the extreme temperatures generally used in thermal spraying techniques; the process temperature does not surpass $1000^{\circ} \mathrm{C}$ [100]. In this way, high purity coatings with compressive residual stresses are obtained [43]. Additionally, the cold spray technique permits one to have a high focused beam of feedstock, allowing precise deposition, with lateral dimension of the order of $\mathrm{mm}$. This is in contrast to the broad beam of thermal spray techniques [43]. Cold spraying is recognized as a promising spray technique capable of producing thick metal, and in some cases metal-ceramic coatings on metal or ceramic substrates at relatively low temperatures, preserving the initial phase composition of feedstock material [100]. For this reason, cold spray is proposed as an alternative to produce hydroxyapatite coatings with controlled crystallinity, compared to traditional thermal spray techniques [101]. However, 
these techniques are not yet employed for the deposition of bioactive glass coatings, but might be the focus of future research.

Table 1 reports the different bioactive glass coatings obtained using the thermal spraying techniques discussed above.

Table 1. Summary of bioactive glass coatings obtained by thermal spraying techniques.

\begin{tabular}{|c|c|c|c|c|}
\hline Coating Material & Substrate & Technique & Coatings' Characteristics & Ref. \\
\hline $45 \mathrm{~S} 5$ & AISI 304 & $\begin{array}{l}\text { Atmospheric plasma } \\
\text { spraying (APS) }\end{array}$ & $\begin{array}{l}\text { Typical splat-like microstructure with } \\
\text { peak and valley surface }\end{array}$ & [34] \\
\hline Biovetro $^{\circledR}$ & Ti6Al4V & APS & $\begin{array}{l}\text { Surface with wide superficial area of } \\
\text { microcavities with round grains }\end{array}$ & [39] \\
\hline $\begin{array}{c}46.1 \mathrm{SiO}_{2}-24.4 \mathrm{Na}_{2} \mathrm{O}- \\
26.9 \mathrm{CaO}- \\
2.6 \mathrm{P}_{2} \mathrm{O}_{5}(\mathrm{~mol} \%)\end{array}$ & Ti6Al4V & APS & $\begin{array}{l}\text { Surface completely molten, cross-section } \\
\text { continuous and uniform deposited }\end{array}$ & [40] \\
\hline P1, P2 & AISI 316L & APS & $\begin{array}{l}\text { Microhardness of the coating } 4.7-5.2 \mathrm{GPa} \text {; } \\
\text { thickness of M1 } 389.8 \pm 5.4 \mu \mathrm{m} \\
\text { M2 } 91.2 \pm 8.2 \mu \mathrm{m}, \mathrm{M} 3262.6 \pm 5.4 \mu \mathrm{m} \\
\text { and M4 } 80.8 \pm 6.5 \mu \mathrm{m} \text {; adhesion strength } \\
\text { of M1 } 2.7 \pm 0.5 \mathrm{MPa} \text { M2 } 3.7 \pm 0.2 \mathrm{MPa} \\
\text { M3 } 3 \pm 0.007 \mathrm{MPa}, \mathrm{M} 44.4 \pm 0.1 \mathrm{MPa}\end{array}$ & [51] \\
\hline $45 \mathrm{~S} 5$ & $\begin{array}{c}\text { Pure } \\
\text { Titanium }\end{array}$ & APS & $\begin{array}{c}\text { Bonding strength of } \mathrm{BG}+\text { bond coat } \\
\text { average } 27.18 \pm 2.24 \mathrm{MPa} \text {, and of } \mathrm{BG} \\
\text { average } 8.56 \pm 0.57 \mathrm{MPa} \text {. }\end{array}$ & [53] \\
\hline $\begin{array}{c}50 \mathrm{SiO}_{2}-20 \mathrm{Na}_{2} \mathrm{O}- \\
16 \mathrm{CaO}-6 \mathrm{P}_{2} \mathrm{O}_{5^{-}} \\
5 \mathrm{~K}_{2} \mathrm{O}-0.2 \mathrm{Al}_{2} \mathrm{O}_{3^{-}} \\
1 \mathrm{MgO}(\text { wt. } \%)\end{array}$ & Ti6Al4V & APS & Thickness $50-100 \mu \mathrm{m}$ & [55] \\
\hline $45 S 5$ & AISI 304 & APS & $\begin{array}{l}\text { Roughness of coatings and contact angle } \\
\text { H-RD125-63 } 16 \pm 4 \mu \mathrm{m}, 24^{\circ} \pm 5^{\circ} ; \\
\text { L-DR125-63 } 16 \pm 5 \mu \mathrm{m}, 31^{\circ} \pm 10^{\circ} \\
\text { HWR } 23 \pm 5 \mu \mathrm{m}, 20^{\circ} \pm 10^{\circ} \\
\text { LWR } 25 \pm 4 \mu \mathrm{m}, 20^{\circ} \pm 10^{\circ} \\
\text { LDR63 } 8 \pm 2 \mu \mathrm{m} .74^{\circ} \pm 6^{\circ}\end{array}$ & [58] \\
\hline $\begin{array}{l}\text { Soda lime silicate, } \\
\text { Cerfav Z5M, } \\
\text { Escol ARB342B, Schott } \\
\text { G017-209, Cerfav T1 }\end{array}$ & AISI 316L & APS & $\begin{array}{l}\text { The predicted trends about splat } \\
\text { formation. Typical morphological aspects } \\
\text { of splats: unmolten core, peripheral thin } \\
\text { film and post-splat coalescence }\end{array}$ & {$[60]$} \\
\hline Bioglass ${ }^{\circledR}$ & Ti6Al4V & APS & $\begin{array}{l}\text { BG amorphous, whereas two different } \\
\text { phases in BG/HA }\end{array}$ & [63] \\
\hline BG & Ti6Al4V & APS & $\begin{array}{l}\text { Thickness HA } 115-145 \mu \mathrm{m} \text {; HA/BG } \\
100-130 \mu \mathrm{m} \text {. Bond strength } 50-60 \mathrm{MPa}\end{array}$ & [64] \\
\hline SrBG & Ti6Al4V & APS & $\begin{array}{l}\text { Maximal shear strength after } \\
\text { implantation: } 6 \text { weeks } 4 \mathrm{MPa} ; 12 \text { weeks } \\
5 \mathrm{MPa} \text { and } 24 \text { weeks } 6 \mathrm{MPa}\end{array}$ & [66] \\
\hline 45S5, Bio K & Titanium & APS & $\begin{array}{c}\text { Thickness } 45 \mathrm{~S} 5150 \mu \mathrm{m} \text {; thickness } \\
\text { BioK } 220 \mu \mathrm{m}\end{array}$ & [102] \\
\hline Bio-K & Titanium & $\begin{array}{l}\text { High velocity } \\
\text { suspension flame } \\
\text { spraying (HVSFS) }\end{array}$ & $\begin{array}{c}\text { The glass structure was maintained; } \\
\text { thickness } 10-15 \mu \mathrm{m} \text {, deposition } \\
\text { efficiency } 30 \%\end{array}$ & [72] \\
\hline $45 \mathrm{~S} 5$ & $\begin{array}{l}\text { Grade } 2 \\
\text { Titanium }\end{array}$ & HVSFS & $\begin{array}{l}\text { The coatings are entirely glassy. } \\
\text { The thickness } 41-83 \mu \mathrm{m} \text {; nano hardness } \\
3-5 \mathrm{GPa} \text {; the elastic modulus } 40-57 \mathrm{GPa}\end{array}$ & [74] \\
\hline Bio-K & $\begin{array}{l}\text { Grade } 2 \\
\text { Titanium }\end{array}$ & HVSFS & $\begin{array}{l}\text { The sprayed coatings are amorphous, } \\
\text { and the first layer deposited is thinner } \\
\text { than the subsequent }\end{array}$ & [78] \\
\hline $\begin{array}{c}33.30 \mathrm{SiO}_{2}-13.30 \mathrm{P}_{2} \mathrm{O}_{5^{-}} \\
48.20 \mathrm{CaO}-0.03 \mathrm{CaF}_{2}{ }^{-} \\
1.90 \mathrm{Al}_{2} \mathrm{O}_{3}-1.92 \mathrm{MgO}(\text { wt. } \%)\end{array}$ & Titanium & HVSFS & $\begin{array}{l}\text { Coatings with limited porosity and good } \\
\text { cohesion; microhardness } 2.42 \pm 0.29 \mathrm{GPa}\end{array}$ & [79] \\
\hline
\end{tabular}


Table 1. Cont.

\begin{tabular}{|c|c|c|c|c|}
\hline Coating Material & Substrate & Technique & Coatings' Characteristics & Ref. \\
\hline Bio-K & Titanium & HVSFS & $\begin{array}{c}\text { Coatings are entirely glassy. Tensile } \\
\text { adhesion strength without bond coat: } \\
\text { BioK-1 } 7 \mathrm{~N} / \mathrm{mm}^{2} \text {, BioK-2 } 3.8 \mathrm{~N} / \mathrm{mm}^{2} \text {, } \\
\text { BioK-3 } 5 \mathrm{~N} / \mathrm{mm}^{2} \text {, BioK-4 } 9.8 \mathrm{~N} / \mathrm{mm}^{2} \\
\text { BioK-5 } 8 \mathrm{~N} / \mathrm{mm}^{2} \text {. With bond coat } \\
\text { BioK-1 } 4 \mathrm{~N} / \mathrm{mm}^{2} \text {, BioK-2 } 5 \mathrm{~N} / \mathrm{mm}^{2} \text {, } \\
\text { BioK-3 } 3 \mathrm{~N} / \mathrm{mm}^{2} \text {, BioK-4 } 9.8 \mathrm{~N} / \mathrm{mm}^{2} \\
\text { BioK-5 } 16 \mathrm{~N} / \mathrm{mm}^{2}\end{array}$ & [80] \\
\hline $\begin{array}{c}\text { 37.6 } 6 \mathrm{SiO}_{2}, 21.9 \mathrm{Na}_{2} \mathrm{O} \\
15.2 \mathrm{CaO}_{2}, 4.44 \mathrm{Al}_{2} \mathrm{O}_{3} \\
12.8 \mathrm{~B}_{2} \mathrm{O}_{3}, 0.54 \mathrm{MgO}^{\prime} \\
1.11 \mathrm{~K}_{2} \mathrm{O}, 0.14 \mathrm{Fe}_{2} \mathrm{O}_{3} \\
0.11 \mathrm{TiO}_{2}, 0.075 \mathrm{P}_{2} \mathrm{O}_{5} \\
\text { (wt.\%) }\end{array}$ & $\begin{array}{l}\text { Grade } 2 \\
\text { Titanium }\end{array}$ & HVSFS & $\begin{array}{c}\text { Roughness average } 1.235 \pm 0.19 \mu \mathrm{m} \\
\text { thickness } 25 \pm 0.3 \mu \mathrm{m}\end{array}$ & [83] \\
\hline BG-Ca/Mix & $\begin{array}{l}\text { Grade } 2 \\
\text { Titanium }\end{array}$ & $\begin{array}{l}\text { HVSFS and } \\
\text { suspension plasma } \\
\text { spraying (SPS) }\end{array}$ & $\begin{array}{l}\text { HVSFS coating very dense and thin. } \\
\text { Hardness 396-516 HV; elastic modulus } \\
\text { 61-95 GPa. Thickness } 20-50 \mu \mathrm{m} \text {. } \\
\text { SPS coatings thickness } 50 \mu \mathrm{m}\end{array}$ & [84] \\
\hline BG_Ca/HA & $\begin{array}{l}316 \mathrm{~L} \\
\text { Stainless } \\
\text { Stell }\end{array}$ & SPS & $\begin{array}{l}\text { Coatings compact and with continuous } \\
\text { thickness with limited presence of pore }\end{array}$ & [26] \\
\hline BG_Ca glass & Ti6Al4V & SPS & $\begin{array}{l}\text { Coatings continuous and homogeneous } \\
\text { thickness } 31-40 \mu \mathrm{m} \text {; hardness } 34-98 \mathrm{HV} \text {; } \\
\text { elastic modulus } 16-23 \mathrm{GPa} \text { and critical } \\
\text { load } 18-21 \mathrm{~N}\end{array}$ & [61] \\
\hline $\begin{array}{c}47.6 \mathrm{SiO}_{2}-5.3 \mathrm{P}_{2} \mathrm{O}_{5} \\
\text { 23.1CaO-24.0 }\end{array}$ & AISI 304 & SPS & $\begin{array}{l}\text { Amorphous coatings with porous } \\
\text { microstructure. Thickness } 20 \mu \mathrm{m} \text { and } \\
\text { thickness with bond coat } 60 \mu \mathrm{m} \text {. Surface } \\
\text { roughness } 10.9 \pm 0.8 \mu \mathrm{m} \text { and with bond } \\
\text { coat } 12 \pm 0.4 \mu \mathrm{m}\end{array}$ & [68] \\
\hline $\begin{array}{c}47.6 \mathrm{SiO}_{2}-5.3 \mathrm{P}_{2} \mathrm{O}_{5}- \\
\text { 23.1 } \mathrm{CaO}-24.0 \mathrm{Na}_{2} \mathrm{O} \text { (wt.\%) }\end{array}$ & AISI 304 & SPS & $\begin{array}{l}\text { All coatings exhibited similar porous } \\
\text { microstructure and analogous thickness }\end{array}$ & [89] \\
\hline BG_Ca/HA & $\begin{array}{l}316 \mathrm{~L} \\
\text { Stainless } \\
\text { Steel }\end{array}$ & SPS & $\begin{array}{l}\text { Glass topcoat with high roughness and } \\
\text { porosity. Thickness } 20 \mu \mathrm{m}\end{array}$ & [90] \\
\hline BG_Ca/HA & $\begin{array}{l}316 \mathrm{~L} \\
\text { Stainless } \\
\text { Steel }\end{array}$ & SPS & $\begin{array}{l}\text { Critical load composite } 27.1 \pm 0.8 \mathrm{~N} \text { and } \\
\text { duplex } 21.2 \pm 1.7 \mathrm{~N}\end{array}$ & [91] \\
\hline $45 \mathrm{~S} 5$ & AISI 304 & $\begin{array}{l}\text { Solution precursor } \\
\text { plasma spraying } \\
\text { (SPPS) }\end{array}$ & Uniform coating average thickness $35 \mu \mathrm{m}$ & [93] \\
\hline $45 S 5$ & AISI 304 & SPPS & $\begin{array}{l}\text { Uniform coating surface. Critical load } \\
5 \mathrm{~N} \text { and scratch hardness } 1.27 \mathrm{GPa}\end{array}$ & [97] \\
\hline P0, P2 & $\begin{array}{l}\text { AISI 316L } \\
\& \text { Ti6Al4V }\end{array}$ & Flame spraying (FS) & $\begin{array}{l}\text { Microstructure consists of melted } \\
\text { particles, pores and both vertical and } \\
\text { parallel cracks. Thickness } 126-275 \mu \mathrm{m} \text {; } \\
\text { fracture toughness } 5-7 \mathrm{MPa} / \mathrm{m}^{1 / 2} \text {; } \\
\text { Vickers hardness } 4-5 \mathrm{HV}\end{array}$ & [98] \\
\hline
\end{tabular}

\subsection{Enamelling}

"Enamel" indicates a glass-like coating fused on metallic substrates; enamelling is a simple and low-cost method to coat metallic implants, as well as to strength ceramics substrates such as alumina or zirconia [102-105] or alumina-zirconia composites, which are found to be highly dense and mechanically promising for load-bearing applications [106]. Enamels were firstly applied on precious metals; subsequently, the enamelling technique was used to produce bioactive glass and glass-ceramic coatings on orthopaedic implants [107]. A piece of bioactive glass or a powder bioactive glass suspension is deposited on the metallic substrate, and then the bioactive glass is glazed using a 
proper heat treatment [31]. Bioactive glass powders are often dispersed in a liquid medium to obtain slurries, which can be applied on metallic substrates by spraying, dipping, etc., to develop the coatings. After the drying of the powders, a thermal treatment is carried out following some requirements such as the firing time, which should be as short as possible, and the firing process which should be performed with an appropriate temperature. The temperature is usually between the bioactive glass transition temperature $\left(T_{\mathrm{g}}\right)$ and its crystallization temperature $\left(T_{\mathrm{c}}\right)$, to guarantee the softening and sintering of bioactive glasses without inducing its crystallization. Certain glass compositions, such as 45S5, suffer from crystallization phenomena at relatively low temperatures, limiting their use in enamelling processes. The addition of alkaline oxides into a bioactive glass [108-110] allows one to increase the crystallization temperature, and this helps to limit the devitrification during the enamelling process. Coatings with interesting local mechanical properties and crack-free interface with the titanium substrate were developed, starting from bioactive glasses with low tendency to devitrification [111,112]. Despite the high crystallization temperature of bioactive glasses, a partial devitrification occurred during enamelling. Nevertheless, the coatings still preserved their apatite-forming ability in SBF, thanks to the survival of a rich amorphous phase [112]. As discussed earlier, in most biomedical applications, bioactive glasses exhibit higher osteoconductivity and higher ability to form an integrated bond with bone and soft tissues, compared to crystalline substances [113]. Therefore, the optimization of temperature is important, in terms of final nature (i.e., amorphous or crystalline) of the coating to preserve its amorphous nature. Furthermore, the substrate is influenced by the temperature of the enamelling process as well. Such temperature should not degrade the substrate or induce transformation, such as the $\alpha \rightarrow \beta$ phase transformation of Ti6Al4V alloy (at $950^{\circ} \mathrm{C}$ ). Therefore, to avoid the crystallization of bioactive glass coating, the degradation of the substrate and an extensive reaction between bioactive glasses and metallic substrates, a careful optimization of both temperature and time during the process is necessary. In general, the degree of adhesion between the bioactive glass coating and the metallic substrate depends on (i) glass composition and its structural characteristics, (ii) surface roughness [114] and (iii) the procedure used to apply coatings. The conventional enamelling theory suggests that the bioactive glass in contact with metallic implants should be saturated with the lowest valence oxide of the metal, without any interfacial layers. In such way, a transition region is formed between the ionocovalent bonding of bioactive glass and the metallic bonding of the substrate, providing a continuity of structure which guarantees an adequate bonding between the bioactive glass and the metallic substrate. However, to realize adherent coatings, the choice of bioactive glasses should be done considering the need of matching the substrate coefficient of thermal expansion (CTE). In fact, the main drawback of enamelling is the possible development of thermal residual stresses, which may be due to the mismatch of the CTEs of the substrate and the glass. Therefore, the difference between CTE of bioactive glasses and CTE of substrates should be as small as possible [48,107]. Different solutions have been suggested to solve the CTE mismatch problem. To match the thermal expansion coefficient of a bioactive glass to that of substrate, the glass composition can be tailored by adding different oxides such as $\mathrm{MgO}, \mathrm{K}_{2} \mathrm{O}$ or $\mathrm{SrO}$, to have similar coefficients to metallic substrates [115]. This approach may be further developed creating a multi-layered system or a functionally graded coating, whose smooth change in composition and thermo- mechanical properties avoids any abrupt interface [116]. To minimize the stress at the interface between the implant and bioactive glass, another bioactive glass with an intermediate CTE was applied in the middle by Kim et al. [117]. On the other hand, a functionally graded coating was developed by Fujino et al. [118], to enhance bioactivity and to increase the long-time chemical stability of the coating. Silicate-based glasses with compositions tailored to match the thermal expansion coefficient of a Co-Cr alloy were developed by varying the different amount of $\mathrm{MgO}, \mathrm{K}_{2} \mathrm{O}$ [118]. Furthermore, the influence of the incorporation of different amounts of $\mathrm{SrO}$ on glass transition temperature, Young's modulus and critical strain energy release rate $\left(\mathrm{G}_{\mathrm{IC}}\right)$ was investigated by $\mathrm{Li}$ et al. [119]. The $T_{\mathrm{g}}$ of bioactive glass increased with increasing $\mathrm{SrO}$ content; the $T_{\mathrm{g}}$ was positively correlated to the Young's modulus. The increase of the $T_{\mathrm{g}}$ was linked also with the increasing of $\mathrm{G}_{\mathrm{IC}}$. Therefore, the incorporation of $\mathrm{SrO}$ enhances the fracture toughness 
of the glass coating/Ti6Al4V substrate system. GIC decreased with the increasing degradation of bioactive glass coating $[111,119,120]$. The degradation decreased with increasing SrO and could be influenced by tensile residual stresses; in fact, tensile residual stresses in the coating could promote its dissolution rate and solubility [121]. Therefore, the mechanical behaviour of implant's surface is important during the time period before complete osseointegration [122]. Since the percentage of thickness reduction was related to the percentage of weight loss, the residual glass thickness with increasing degradation time indicated that cracks grew closer to the interface between bioactive glass coatings and metallic substrates [111]. Thicker coatings result in a large crack driving force due to residual stresses; on the other hand, thinner coatings are significantly less prone to cracking or delamination [123]. Thus, thin coatings guarantee a good functioning of the implant compared to thick coatings. Another way to stabilize bioactive glass coatings is a preconditioning treatment prior to implantation. Foppiano et al. [124] showed that, by soaking samples in SBF before implantation, the bond with bone is favoured thanks to the hydroxycarbonate apatite (HCA) already present on coatings' surface. Bioactive glass coatings could induce a selective gene expression which is important for osteoblast differentiation. Bioactive glass induces an increase in Runx- 2 which is an osteoblast specific transcription factor required for the differentiation of mesenchymal progenitor cells towards the osteoblastic lineage. Therefore, in vivo bioactive glass coating could promote the differentiation of mesenchymal stem cells towards the osteoblastic lineage, by stimulating Runx-2 [124]. Furthermore, pre-conditioning treatments were also performed on the functionally graded bioactive glass coatings (FCGs), even if FGCs were suitable substrates for cell culture without any prior surface modification [125]. A pre-conditioning treatment is recommended to make the surface Ca-P rich, with a protective effect on the underlying glass; this could help in preserving the integrity of the coating under physiological fluids, which could compromise the coating integrity [125].

Table 2 summarizes the different bioactive glass coatings obtained by enamelling technique.

Table 2. Summary of bioactive glass coatings obtained by enamelling technique.

\begin{tabular}{|c|c|c|c|}
\hline Coating Material & Substrate & Coatings' Characteristics & Ref. \\
\hline 45S5, Bio K & Alumina & $\begin{array}{l}\text { Bio K completely amorphous, } 45 \mathrm{~S} 5 \text { some } \\
\text { crystalline phases; both compact coatings. } \\
\text { Vickers hardness } 157 \pm 39 \mathrm{HV} \text {, } \\
146 \pm 28 \mathrm{HV} 45 \mathrm{~S} 5\end{array}$ & [102] \\
\hline RKKP, AP40 & Zirconia & $\begin{array}{l}\text { Well adherent coatings, thickness } 350 \mu \mathrm{m} \text {; } \\
\text { shear strength } 80 \pm 3 \mathrm{MPa}\end{array}$ & [103] \\
\hline RKKP, AP40 & Zirconia & $\begin{array}{c}\text { Coatings with good mechanical properties } \\
\text { and improved biocompatibility. ALP activity } \\
1 \mathrm{~d} 3.91 \pm 1.15 \mu \mathrm{M} \mathrm{AP} 40,4.69 \pm 2.10 \mu \mathrm{M} \\
\text { RKKP. } 9.98 \pm 0.80 \mu \mathrm{M} \text { AP } 40 \text { and } \\
9.94 \pm 2.90 \mu \mathrm{M} \text { RKKP at } 5 \text { and } 10 \text { days }\end{array}$ & [104] \\
\hline $\begin{array}{l}\text { Ground coat glass, } \\
\text { bioactive cover glass }\end{array}$ & Alumina & $\begin{array}{l}\text { Homogeneous coating with high } \\
\text { in vitro bioactivity }\end{array}$ & [105] \\
\hline 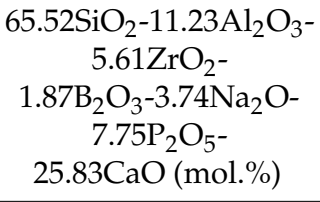 & ZTA, AZT & $\begin{array}{c}\text { Coating perfectly adherent to substrate. } \\
\text { Density } 2.4 \mathrm{~g} / \mathrm{cm}^{3}, \text { hardness } 8.3 \pm 0.2 \mathrm{GPa} \text {, } \\
\text { toughness } 1.3 \pm 0.3 \mathrm{MPam}^{1 / 2}, \text { Young modulus } \\
90.1 \pm 2.1 \mathrm{GPa}\end{array}$ & [106] \\
\hline SCK & $\begin{array}{l}\text { Full density medical } \\
\text { grade } \alpha \text {-alumina }\end{array}$ & $\begin{array}{l}\text { Good adhesion. Coating without pores or } \\
\text { bubbles at the interface. Thickness } 70-100 \mu \mathrm{m}\end{array}$ & [107] \\
\hline Ly-B0, Ly-B3, Ly-B5 & Ti6Al4V & Thickness 95-105 $\mu \mathrm{m}$ & [111] \\
\hline
\end{tabular}


Table 2. Cont.

\begin{tabular}{|c|c|c|c|}
\hline Coating Material & Substrate & Coatings' Characteristics & Ref. \\
\hline $\begin{array}{c}\text { BG_Ca, BG_Ca/Mix } \\
\text { BG_Ca_K }\end{array}$ & Ti6Al4V & $\begin{array}{c}\text { Uniform and well distributed coatings. } \\
\text { Thickness BG_Ca } 108 \mu \mathrm{m}, \mathrm{BG} \_\mathrm{Ca} / \mathrm{Mix} 113 \mu \mathrm{m}, \\
\text { BG_Ca_K } 121 \mu \mathrm{m} \text {; Vickers hardness BG_Ca } \\
232.1 \pm 76.8 \mathrm{HV}, \mathrm{BG} \_\mathrm{Ca} / \mathrm{Mix} 329.0 \pm 81.0 \mathrm{HV} \\
\text { BG_Ca_K } 317.9 \pm 48.8 \mathrm{HV}\end{array}$ & [112] \\
\hline BG, 6P57, 6P68, HA & Ti6Al4V & $\begin{array}{c}\text { Good adhesion with cracks propagation } \\
\text { along the glass without } \\
\text { interface delamination }\end{array}$ & [115] \\
\hline $\begin{array}{l}\text { Ground Coat, } \\
\text { Bio-Enamel }\end{array}$ & $\begin{array}{l}\text { Medical grade } \\
\text { of titanium } \\
\text { (ASTM grade 2) }\end{array}$ & $\begin{array}{l}\text { Homogeneous and reactive coatings. } \\
\text { Faster HCA formation }\end{array}$ & [117] \\
\hline $\begin{array}{l}\text { Bioglass }{ }^{\circledR}, 6 \mathrm{p} 44-\mathrm{a} \\
\text { 6p44-b, 6p44-c, 6p50, } \\
\text { 6p53-a, 6p55, 6p57, } \\
\text { 6p61, 6p64, 6p68 }\end{array}$ & $\begin{array}{l}\text { Vitallium }{ }^{\circledR}, \\
\text { Co-Cr-alloy }\end{array}$ & $\begin{array}{c}\text { Thickness } 25-60 \mu \mathrm{m} \text {. Crack propagation in } \\
\text { the glass not along interface }\end{array}$ & [118] \\
\hline $\begin{array}{l}\text { LY-B0, LY-B1, } \\
\text { LY-B2, } \\
\text { LY-B3, LY-B4, } \\
\text { LY-B5 }\end{array}$ & Ti6Al4V & $\begin{array}{c}\text { Thickness } 90-100 \mu \mathrm{m} \text {; critical strain energy } \\
\text { release } 6.56-14.61 \mathrm{~J} / \mathrm{m}^{2}\end{array}$ & [119] \\
\hline $\begin{array}{l}\text { SRT0, SRT1, SRT3, BRT0, } \\
\text { BRT1, BRT3 }\end{array}$ & Ti6Al4V & $\begin{array}{c}\text { Critical strain energy release SRT0, SRT1, } \\
\text { SRT3 } 12.08 \pm 1.72 \mathrm{~J} / \mathrm{m}^{2}, \text { BRT0, BRT1, } \\
\text { BRT3 } 18.50 \pm 1.60 \mathrm{~J} / \mathrm{m}^{2}\end{array}$ & [120] \\
\hline $\begin{array}{c}56.6 \mathrm{SiO}_{2}-15 \mathrm{CaO}-11 \mathrm{Na}_{2} \mathrm{O}- \\
8.5 \mathrm{MgO}- \\
6 \mathrm{P}_{2} \mathrm{O}_{5}-3 \mathrm{~K}_{2} \mathrm{O}(\mathrm{wt} . \%)\end{array}$ & Ti6Al4V & $\begin{array}{l}\text { Absence of porosities and good adhesion. } \\
\text { Hardness } 0.59-1.014 \mathrm{GPa} \text {; modulus } \\
0.87-4.459 \mathrm{GPa} \text { depending on load }(\mu \mathrm{N}) \text {. } \\
\text { Coefficient of friction } 0.209-0.285\end{array}$ & [122] \\
\hline SRT0 & Ti6Al4V & $\begin{array}{l}\text { Thickness } 84-408 \mu \mathrm{m} \text {; residual stresses } \\
5-18 \mathrm{MPa}\end{array}$ & [123] \\
\hline 6Р61, 6P55 & Ti6Al4V & $\begin{array}{l}\text { No modification in the structure of coating } \\
\text { after preconditioning treatment }\end{array}$ & [124] \\
\hline 6P61, 6P55 & Ti6Al4V & Some small pores. Thickness $86.0 \pm 11.5 \mu \mathrm{m}$ & [125] \\
\hline
\end{tabular}

\subsection{Sol-Gel}

The sol-gel method was designed to obtain bioactive glasses that cannot be obtained by the conventional melt-quenching route. This method is a low temperature technique to produce ceramics or bioactive glasses by chemical route. In the sol-gel system colloidal particles are dispersed, and the stability of such particles can be modified by reducing their surface charge. The success of the sol-gel method is due to the possibility of fabricating a wide range of bioactive glasses, giving them a controlled porous microstructure [126]. The sol-gel method is currently used to obtain both bulk and coating bioactive glasses [48]. To fabricate coatings, the sol-gel method can be performed by a dip coating process employed for large samples with complex shape, or by spin coating usually employed for smaller samples with flat surface. This technique offers a convenient and cheaper method to coat metallic implants compared to conventional thermal spraying techniques, which require high temperature, mixture of gases and high energy. Coatings produced by sol-gel method show higher chemical and physical homogeneity, with better structural integrity and purity compared to coatings obtained by other routes [127].

Additionally, coatings obtained by the sol-gel method present the possibility to functionalize the coatings themselves, by adding particles and/or by the presence of organic groups [128]. Therefore, the bioactivity of coatings can be improved by tailoring the composition of bioactive glasses; furthermore, protective coatings can be realized. The corrosion resistance of metallic implants determines the life 
term; with regard to this, an eventual high corrosion resistance of coatings protects the surrounding environment from the releasing of a large concentration of metallic cations which can affect cell metabolism [129-131]. Some coated systems present an interlayer of silica to prevent the contact of electrolytes with the substrate, after the dissolution of bioactive glass coating in physiological fluids $[6,7,132]$. This silica interlayer has the aim to increase the barrier effects of coatings when the bioactive glass coating dissolves [6,132]. García et al. and Omar et al. [6,132] developed bioactive glass coatings which showed higher corrosion resistance compared to the pure AISI 316L substrates in SBF solution. Anyway, high corrosion resistance coatings without interlayers were developed by the sol-gel method [6,14,132]. For instance, coatings developed by Fathi et al. [14] showed good properties: these bioactive glass coatings showed higher corrosion resistance compared to uncoated 316L SS, both in saline solution and Ringer's solution. The corrosion resistance is related to the morphology and defects of the coated surface. In fact, the presence of some structural imperfection generated by preferential dissolution of un-decomposed chemical reagents (i.e., $\mathrm{NaNO}_{3}$ ) [133] allows electrolytes of the surrounding solution to come in contact with the substrate. These imperfections were detected on non-mesoporous and mesoporous $45 \mathrm{~S} 5$ bioactive glass coatings developed by Huang et al. [133]. The infiltration into the inner portion of coatings through structural imperfections (i.e., pores and cracks) initiates the corrosion phenomena $[134,135]$. The presence of imperfections affects the biocompatibility as well; in fact, it has been reported that a decrease in cell viability could be due to non-homogenous coatings [136]. A good balance between corrosion resistance and biocompatibility should be found, because the corrosion behaviour is essential, as well as the capability of mineralization in vivo, to guarantee a good performance of implants [132,137]. Hence, a successful corrosion resistance of bioactive glass coatings goes hand in hand with its good biocompatibility and its bioactivity [14]. When bioactive glasses react with body fluids, both chemical and structural changes occur as a function of time within the bioglass surface [138]. Furthermore, the incorporation of different oxides (i.e., $\mathrm{Ag}_{2} \mathrm{O}$ and $\mathrm{ZnO}$ ) into a bioactive glass composition could decrease its bioactivity [139-142]. When Ag ions are added to a bioactive glass, for example, antibacterial activities are introduced at the expense of the solubility of bioactive glass coating in SBF [141,142]. The decrease in hydroxycarbonate apatite (HCA) formation could favour the direct contact between coatings and the surrounding environment. However, the incorporation of $\mathrm{Ag}_{2} \mathrm{O}$ aims at developing coatings capable of releasing antimicrobial agents (i.e., Ag ions) at the implant site. Experimental data have shown that the antibacterial activity is directly proportional to the silver percentage [142]. By tailoring the amount of $\mathrm{Ag}_{2} \mathrm{O}$, it is possible to avoid serious failure that requires long-term antibiotic therapy, the removal of prosthesis and bone reconstruction [142].

Table 3 summarizes the different bioactive glass coatings obtained by the sol-gel method.

Table 3. Summary of bioactive glass coatings obtained by sol-gel method.

\begin{tabular}{|c|c|c|c|}
\hline Coating Material & Substrate & Coatings' Characteristics & Ref. \\
\hline 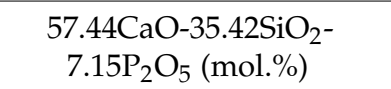 & 316L stainless steel & $\begin{array}{c}\text { Homogeneous and crack free coating. } \\
\text { Thickness } 1.5-2 \mu \mathrm{m}\end{array}$ & {$[6]$} \\
\hline $45 \mathrm{~S} 5, \mathrm{SiO}_{2}$ & 316L stainless steel & $\begin{array}{l}\text { Amorphous coatings; adhesion strength } \\
0.5-5 \mathrm{MPa}\end{array}$ & [7] \\
\hline $\begin{array}{l}57.44 \mathrm{CaO}-35.42 \mathrm{SiO}_{2-} \\
7.15 \mathrm{P}_{2} \mathrm{O}_{5}(\mathrm{~mol} . \%)\end{array}$ & 316L stainless steel & $\begin{array}{l}\text { Crack free and homogeneous coatings } \\
\text { spread properly. Thickness } 10-20 \mu \mathrm{m}\end{array}$ & {$[14]$} \\
\hline $\begin{array}{l}\text { Bioglass(C, 6P44-a, 6P44-b, } \\
\text { 6P44-c, 6P53-a, 6P53-b, } \\
\text { 6P55, 6P57, 6P61, 6P68 }\end{array}$ & $\begin{array}{c}\text { Titanium, Ti6Al4V, } \\
\text { Vitallium (C, Co-Cr alloy }\end{array}$ & $\begin{array}{c}\text { Coatings without cracks or delamination. } \\
\text { Hardness } 5.3-6.3 \mathrm{GPa} \text {; } \\
\text { density } 2.5-2.7 \mathrm{~g} / \mathrm{cm}^{3}\end{array}$ & [48] \\
\hline 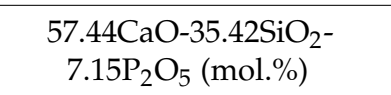 & $\begin{array}{l}\text { CrCoMo alloy, Ti6Al4V, } \\
\text { AISI 316L }\end{array}$ & $\begin{array}{l}\text { Glassy matrix with some defects and } \\
\text { cracks. Thickness } 1.5-3 \mu \mathrm{m}\end{array}$ & [128] \\
\hline $\mathrm{BG}, \mathrm{BGSr}$ & AISI 316L & $\begin{array}{l}\text { Homogeneous coatings without the } \\
\text { presence of flaws. Thickness } 2.1 \pm 0.4 \mu \mathrm{m}\end{array}$ & [132] \\
\hline
\end{tabular}


Table 3. Cont.

\begin{tabular}{cccc}
\hline Coating Material & Substrate & Coatings' Characteristics & Ref. \\
\hline $45 \mathrm{~S} 5 \mathrm{BCG}$ & AZ31 magnesium alloy & $\begin{array}{c}\text { Integrated coatings with some asperities. } \\
\text { Thickness } 1.1 \mu \mathrm{m}\end{array}$ & {$[133]$} \\
\hline $45 \mathrm{~S} 5$ & AZ31 magnesium alloy & $\begin{array}{c}\text { Relative smooth and uniform coatings } \\
\text { with small cracks. Thickness } 1 \mu \mathrm{m}\end{array}$ & {$[135]$} \\
\hline $\begin{array}{c}x \mathrm{CaO}(1-x) \mathrm{SiO}_{2} \\
x=0,0.3,0.4,0.5,0.6\end{array}$ & Ti-4 substrate & Homogeneous and crack free coatings & {$[136]$} \\
\hline $7.15 \mathrm{P}_{2} \mathrm{O}_{5}$ & AISI 316L & $\begin{array}{c}\text { Coatings without cracks and } \\
\text { homogeneous. Thickness 2-4 } \mu \mathrm{m}\end{array}$ & {$[137]$} \\
\hline $\mathrm{Ag}-\mathrm{BG}$ & Titanium & $\begin{array}{c}\text { Homogeneous and without macro and } \\
\text { micro cracks }\end{array}$ & {$[141]$} \\
\hline $70 \mathrm{CaO} 30 \mathrm{C}_{\mathrm{x}} \mathrm{A}$ & Titanium grade 4 & $\begin{array}{c}\text { Homogeneous coating with } \\
\text { antibacterial properties }\end{array}$ & {$[142]$} \\
\hline
\end{tabular}

\subsection{Electrophoretic Deposition}

Electrophoretic deposition (EPD) uses the electrophoresis mechanism for the movement of charged particles suspended in a solution under an electric field, to deposit such particles on a substrate, to develop coatings $[143,144]$. Initially, an electric field is applied between two electrodes; the charged particles being suspended in a suitable liquid move towards the oppositely charged electrode, constituting the electrophoresis step. The particles accumulation at the deposition electrode, which creates a relatively compact and homogeneous coating, is referred to as the deposition step [145]. EDP is a versatile process which can be used to deposit both ceramics and bioactive glasses on metallic substrates. It has a short processing time, simple apparatus setup, and few restrictions on the substrate shape. Additionally, the EPD method permits one to control the temperature and the thickness of coatings on complex shaped substrates [35]. However, it is extremely difficult to develop coatings from more than one material [127]. The purpose of the EDP method is to realize coatings with improved safety, reliability and physiological acceptability of metallic implants, being suitable to replace or improve a function of a part in human body $[36,146]$.

Generally, bioactive glass particles are dispersed in organic solvents $[11,147]$ or in water, to avoid the problem of electrolysis and gas evolution. However, distilled water is preferentially used to avoid the environmental impact of organic solvents [143]. Al-Rashidy et al. [148] used distilled water as solvent, in which borate bioactive glass particles were dispersed in different concentrations (wt.\%). Employing the highest concentration of borate bioactive glass particles and the highest voltage, homogeneous and thick coatings with high corrosion resistance in Dulbecco's Modified Eagle's medium (DMEM) were obtained [147]. The concentration of glass particles and the voltage influence the thickness and the morphology of coatings, as well as the deposition time, the $\mathrm{pH}$ and stability of the suspension. The stability of suspension and the electrophoretic mobility are reflected in the zeta potential. The suspension stability increases with increasing absolute value of zeta potential. More uniform coatings would be realized, whereas a high zeta potential and a suitable value of conductivity were measured $[11,149]$. The obtainment of uniform coatings is essential to guarantee corrosion resistance [150]. In fact, PEEK/Bioglass ${ }^{\circledR}$ coatings developed by Boccaccini et al. [150] protected the NiTi substrate from corrosion in contact with body fluids, impeding the leakage of ions. Furthermore, being bioactive, Bioglass ${ }^{\circledR}$ improved the bonding of bone or soft tissue, through the formation of hydroxycarbonate apatite (HCA). The formation of HCA layer after immersion in SBF solution can play a positive role to slow-up the degradation of bioactive glass and consequently of the substrate, as found in [11].

The EPD method was used to realize coatings on the surface of metallic orthodontic materials by Kawaguchi et al. [151] The coatings were realized to prevent the mineralization of the tooth surface surrounding brackets and enhance mineralization after brackets debonding. Coated samples with 
higher thickness and better interfacial adhesion coating-substrate were obtained, employing high voltage and alternating current. For this specific orthodontic application, the colour and the frictional properties of the coated samples were of pivotal importance. This was the first study investigating the aesthetic performance of the samples: samples coated at higher voltage showed higher reflectance. The colour of orthodontic applications such as brackets should ideally match that of the natural teeth of the patient $[151,152]$. Furthermore, frictional properties are attributed to surface roughness, hardness, elastic modulus, cross-sectional dimension of the orthodontic samples [153]. Better frictional properties were measured for coated samples, using high voltage. Cytotoxicity tests ascertained the non-cytotoxicity of the coated samples [151]. Therefore, the surface modification technique using EPD and bioactive glass for orthodontic stainless steel offers the possibility of developing new orthodontic metallic appliances, with satisfactory aesthetic appearance and remineralization ability, without being cytotoxic [151].

Table 4 summarizes the different bioactive glass coatings obtained by means of electrophoretic deposition (EPD).

Table 4. Summary of bioactive glass coatings obtained by EPD.

\begin{tabular}{|c|c|c|c|}
\hline Coating Material & Substrate & Coatings' Characteristics & Ref. \\
\hline $\begin{array}{l}46.1 \mathrm{SiO}_{2}-51.3 \mathrm{CaO}- \\
2.6 \mathrm{P}_{2} \mathrm{O}_{5}(\mathrm{~mol} \%)\end{array}$ & $\begin{array}{l}\text { Biomedical Grade } \\
\text { AZ91 Mg alloy }\end{array}$ & $\begin{array}{l}\text { Corrosion potential }-1.28-(-1.32) \mathrm{V} \\
\text { corrosion current density } 0.02-0.6 \mu \mathrm{A} / \mathrm{cm}^{2}\end{array}$ & [11] \\
\hline $\begin{array}{c}55 \mathrm{SiO}_{2}-26 \mathrm{CaO}-13 \mathrm{MgO}- \\
6 \mathrm{P}_{2} \mathrm{O}_{5}(\mathrm{~mol} . \%) \\
\mathrm{HA}\end{array}$ & Ti6Al4V & $\begin{array}{l}\text { Homogeneous coatings. Thickness } 15 \mu \mathrm{m} \text {; } \\
\text { adhesive strength } 50 \pm 1 \mathrm{MPa} \text {; corrosion } \\
\text { potential BG } 0.380 \pm 0.5 \mathrm{~V}, \mathrm{HA} 0.325 \pm 0.5 \mathrm{~V} \\
\text { and BG/HA } 0.475 \pm 0.5 \mathrm{~V} \text {; corrosion current } \\
\text { density } 0.22 \pm 0.5\left(\mathrm{~A} / \mathrm{cm}^{2}\right)\end{array}$ & [35] \\
\hline $45 S 5$ & Ti6Al4V & $\begin{array}{c}\text { Coatings with good adhesion without } \\
\text { cracks. Rough surface in which the initial } \\
\text { powder particles are still visible. } \\
\text { Thickness } 50-250 \mu \mathrm{m}\end{array}$ & [147] \\
\hline $\begin{array}{c}60 \mathrm{~B}_{2} \mathrm{O}_{3}-10 \mathrm{CaO}-20 \mathrm{Na}_{2} \mathrm{O}- \\
10 \mathrm{MgO}(\mathrm{mol} \%)\end{array}$ & 316L Stainless Steel & $\begin{array}{c}\text { Homogeneous, compact and crack free } \\
\text { coatings. Thickness } 60 \mu \mathrm{m} \text {; contact angle } \\
60^{\circ} \text {; corrosion rate } 2.963 \mathrm{mpy} \text { in DMEM and } \\
4.533 \mathrm{mpy} \text { in SBF }\end{array}$ & [148] \\
\hline Bioglass ${ }^{\circledR}$ & NiTi Alloy & $\begin{array}{c}\text { Homogeneous microstructure without } \\
\text { cracks or pores with uniform topography. } \\
\text { Thickness } 5-15 \mu \mathrm{m}\end{array}$ & [150] \\
\hline $45 S 5$ & SUS316 & $\begin{array}{l}\text { Amorphous structure. Hardness } \\
0.10-2 \mathrm{GPa} \text {; elastic modulus } 84-193 \mathrm{GPa}\end{array}$ & [151] \\
\hline
\end{tabular}

\subsection{Laser Cladding}

Laser cladding is a deposition technique in which dissimilar materials are bonded together using laser intercession. This technique is based on powder feedstock, which is melted using a laser to form a coating on substrates [154]. Feedstock is injected by a nozzle on the substrate and the laser beam hits the powder flow and melts it producing a coating. As an alternative approach, a powder or paste feedstock is deposited and melted using a laser beam [31]. The laser power, laser beam size (i.e., beam diameter) and the laser scanning velocity influence the quality of coatings. To achieve the desired properties for the coatings, a good control of process parameters is indispensable [154]. The laser cladding technique has been recently investigated in the biomaterials field for the production of small bio-ceramic implants with complex shape $[155,156]$ and coatings [157]. Although much more research on the application of laser cladding has to be done, this technique shows high deposition rate, and substrates are not exposed to high temperature during processing [158]. For this reason, the laser cladding technique can be used to apply bioactive glass coatings, because the amorphous nature of bioactive glasses will be 
preserved. Moreover, bioactive glass coatings can be applied on surfaces with curved geometry [31], compared to other techniques, such as enamelling and thermal spraying, which can easily produce coatings on flat surfaces. The feasibility of laser cladded glass coatings on a curved (3D) geometry was demonstrated by Baino et al. [159], developing bioactive glass coatings on a ceramic acetabular cup for hip joint prosthesis. Two different bioactive glasses were used as feedstock: S57A7 $\left(57 \mathrm{SiO}_{2}-\right.$ $\left.30 \mathrm{CaO}-6 \mathrm{Na}_{2} \mathrm{O}-7 \mathrm{Al}_{2} \mathrm{O}_{3} \mathrm{~mol} . \%\right)$ and S50B2 $\left(50 \mathrm{SiO}_{2}-35 \mathrm{CaO}-7 \mathrm{Na}_{2} \mathrm{O}-6 \mathrm{P}_{2} \mathrm{O}_{5}-2 \mathrm{~B}_{2} \mathrm{O}_{3}\right.$ mol.\%). Highly reproducible coatings were produced independently of the type of glass processed. Coatings exhibited vitreous aspect and $\mathrm{XRD}$ analysis confirmed the prevalent amorphous nature of coatings. However, some crystalline phases such as $\mathrm{CaSiO}_{3}$ and $\mathrm{Ca}_{11} \mathrm{Si}_{4} \mathrm{~B}_{2} \mathrm{O}_{22}$ were detected. The major crystalline phase detected in both materials after high-temperature treatments was $\mathrm{CaSiO}_{3}$, which is known to be biocompatible and suitable for use in bone tissue engineering applications [159]. The possibility to fabricate coatings in a dense or porous form was shown: S57A7 was used to produce a dense coating in direct contact with the substrate, and S50B2 to realize a porous coating on top. Most pores were open and interconnected, which is fundamental in vivo for cells migration, tissues growth and flowing of waste products [160]. Laser cladding coatings showed better adhesion, although their porosity was lower than coatings produced by sponge replication. Although a more extensive investigation on processing parameters, mechanical testing and biological test is needed, adherent and porous coatings on 3D acetabular cups for joint prosthesis were successfully developed [159].

\subsection{Other Techniques}

The coating of metallic substrates with thick bioactive glasses coatings by the traditional coating techniques (i.e., thermal spraying, enamelling) sometimes fails, due to a weak bioactive glass/metal interface and rapid dissolution in body fluids once implanted [161,162]. Thus, in recent years, chemical and laser methods were investigated to prepare adherent thin coatings. The use of thin coatings is safer compared to the use of thick coatings, because of limited problems of adhesion, which could determine in time the loosening of the implant. Physical vapour deposition (PVD), such as pulsed laser deposition (PLD) and pulsed electron deposition (PED), and radio-frequency magnetron sputtering (RF-MS) have been investigated, to produce well adherent and homogenous thin coatings $[163,164]$. Among the various coating techniques, PLD, by changing the deposition parameters (i.e., atmosphere pressure, wavelength, energy density and target-substrate distance [165]), can control surface properties, such as coating thickness, morphology, roughness, chemical composition, and crystallinity. Furthermore, the substrate temperature influences the bonding configuration and the adhesion strength of bioactive glass coatings, as shown by Zhao et al. [166] Coatings deposited at $200{ }^{\circ} \mathrm{C}$ showed higher adhesion strength compared to coatings deposited at 20 and $500{ }^{\circ} \mathrm{C}$, because in the former case, a lower thermal stress caused by temperature gradient occurred, and for the latter, a small quantity of $\mathrm{TiO}_{2}$ was detected on coatings [166]. PLD was also employed to deposit magnesium-containing bioactive glass thin coatings on Ti6Al4V substrates [167] and titanium substrates [168-170].

On the other hand, the PED technique was initially developed for the deposition of thin coatings of metal oxides for spintronics, photovoltaics, superconductivity, and dielectric polymer layers [171-173]. Recently, this technique has been proposed for producing thin coatings for biomedical applications [174]. PED belongs to the family of the channel spark discharge, a type of hollow cathode glow discharge, in which a target material is ablated by the local heating induced by an accelerated electron beam [174]. The target material impacted by the fast-pulsed electrons is emitted in the form of highly ionized plasma (i.e., plasma plume). The plasma plume enters in contact with the substrate, where the material is deposited forming a coating [174]. PED version evolution called ionized jet deposition (IJD) has been employed to deposit thin coatings, with the promise of overtaking the main drawbacks of plasma deposition technique, such as the need of periodically substituting the dielectric tube confining. IJD is characterized by a higher efficiency, and leads to more optimized stoichiometry conservation. This version was employed to produce $45 \mathrm{~S} 5$ and CaK thin coatings on medical grade Ti6Al4V [175]. 
The radio frequency magnetron sputtering (RF-MS) technique is a low-pressure method which benefits from the deposition of uniform coating with controlled thickness [176]. Therefore, RF-MS has been found to be an appropriate coating method for producing uniform thin coatings with superior adhesion strength [177]. RF-MS has emerged for the deposition of thin bioactive glass coatings, because of its low pressure operation, low substrate temperature, high purity and excellent uniformity of coatings [178]. During the sputtering process, the bioactive glass target is bombarded by ions from the plasma, including reactive oxygen ions leading to the formation of coatings. When increasing the reactive gas flow, the degree of target poisoning increases, the sputtering erosion rate reduces, and the deposition rate decrease [179]. The deposition rate, as well as the structure, the thickness, the composition and the biomineralization capability of coatings, are also influenced by the deposition pressure [180,181]. In fact, a possible explanation of a decrease in deposition rate with increasing deposition pressure is that particles suffer of more collisions while traveling towards the substrate with some of the sputtered particles being back-scattered, leading to a decrease in deposition rate [180]. By varying the sputtering pressure, it is possible to influence the quality of hydroxycarbonate apatite (HCA) layer [180,182], which enhances the bond with bone. Furthermore, it has been demonstrated that, by tailoring the composition of bioactive glasses, it is possible to induce specific host response and release specific ions at the implant site [183-186]. Resorbable phosphate-based glasses can be tailored to deliver ions during dissolution, and this advantage could potentially be extended to the production of thin film by RS-MS technique [187].

Table 5 summarizes thin bioactive glass coatings obtained by different techniques.

Table 5. Summary of thin bioactive glass coatings.

\begin{tabular}{|c|c|c|c|c|}
\hline Coating Material & Substrate & Technique & Coatings' Characteristics & Ref. \\
\hline $45 \mathrm{~S} 5$ & Ti6Al4V & PLD & $\begin{array}{l}\text { Coatings uniform without } \\
\text { microcracks and pores. Thickness } \\
1 \mu \mathrm{m} \text {; surface roughness } 6 \mathrm{~nm}\end{array}$ & [165] \\
\hline $45 \mathrm{~S} 5$ & Ti6Al4V & PLD & $\begin{array}{l}\text { Coatings with smooth surface. } \\
\text { Thickness } 1 \mu \mathrm{m} \text {; critical load } \\
17.5 \mathrm{~N} \text { at } 20^{\circ} \mathrm{C}, 22.3 \mathrm{~N} \text { at } 200^{\circ} \mathrm{C} \\
\text { and } 18.9 \mathrm{~N} \text { at } 500^{\circ} \mathrm{C}\end{array}$ & [166] \\
\hline $\begin{array}{l}28 \mathrm{CaO}-10 \mathrm{MgO}- \\
4 \mathrm{P}_{2} \mathrm{O}_{5}-58 \mathrm{SiO}_{2}\end{array}$ & Ti6Al4V & PLD & $\begin{array}{l}\text { High roughness surface and } \\
\text { uniform porous structure. } \\
\text { corrosion potential } \\
-0.100-0.420 \mathrm{~V} \text {; corrosion current } \\
\text { density } 1-9 \mathrm{~A} / \mathrm{cm}^{2}\end{array}$ & [167] \\
\hline $\begin{array}{c}57 \mathrm{SiO}_{2}-15 \mathrm{CaO}-11 \mathrm{Na}_{2} \mathrm{O}- \\
8.5 \mathrm{MgO}-6 \mathrm{P}_{2} \mathrm{O}_{5^{-}} \\
3 \mathrm{~K}_{2} \mathrm{O}(\text { wt. } \%)\end{array}$ & Titanium & PLD & $\begin{array}{l}\text { Amorphous coating with } \\
\text { granular structure }\end{array}$ & [168] \\
\hline 6Р57, 6Р61 & $\begin{array}{l}\text { Titanium grade } \\
4 \text { etched }\end{array}$ & PLD & $\begin{array}{c}\text { Coatings with rough surface. } \\
\text { Studies on in vitro bioactivity } \\
\text { in SBF }\end{array}$ & [169] \\
\hline 6Р57, 6Р61 & Titanium & PLD & $\begin{array}{l}\text { Uniform coatings. Studies on } \\
\text { cell viability }\end{array}$ & [170] \\
\hline 45S5, CaK & Ti6Al4V & PED/IJD & $\begin{array}{l}\text { Surface roughness } 300-390 \mathrm{~nm} \text {; } \\
\text { mean grain size } 170-350 \mathrm{~nm} ; \\
\text { contact angle } 10^{\circ}-46^{\circ}\end{array}$ & [175] \\
\hline $\mathrm{T} 1, \mathrm{~T} 2, \mathrm{~T} 3, \mathrm{~T} 4, \mathrm{~T} 5, \mathrm{~T} 6$ & Titanium & RF-MS & $\begin{array}{c}\text { Amorphous coatings with some } \\
\text { crystalline phases. Thickness } \\
1.8-2.4 \mu \mathrm{m}\end{array}$ & [177] \\
\hline
\end{tabular}


Table 5. Cont.

\begin{tabular}{|c|c|c|c|c|}
\hline Coating Material & Substrate & Technique & Coatings' Characteristics & Ref. \\
\hline $\begin{array}{l}40.08 \mathrm{SiO}_{2}-29.1 \mathrm{CaO}- \\
4.59 \mathrm{Na}_{2} \mathrm{O}- \\
6.32 \mathrm{P}_{2} \mathrm{O}_{5}-8.96 \mathrm{MgO}- \\
5.79 \mathrm{CaF}_{2}-5.61 \mathrm{~B}_{2} \mathrm{O}_{3}\end{array}$ & Silicon wafer & RF-MS & $\begin{array}{l}\text { Amorphous coatings without } \\
\text { microcracks or delamination. } \\
\text { Thickness } 3.5 \mu \mathrm{m}\end{array}$ & [178] \\
\hline BG & Titanium & RF-MS & $\begin{array}{l}\text { Coatings without microcracks or } \\
\text { delamination. Thickness BG2 } \\
510 \mathrm{~nm}, \mathrm{BG} 4380 \mathrm{~nm} \text {; BG5 } 330 \mathrm{~nm} \text {; } \\
\text { average adhesion value } 75 \mathrm{MPa}\end{array}$ & [179] \\
\hline BG1, BG2, BG3 & Silicon & RF-MS & $\begin{array}{l}\text { Coatings without microcracks or } \\
\text { delamination. Smooth surface } \\
\text { with some spherical shaped } \\
\text { agglomerates. Thickness BG1 } \\
646 \mathrm{~nm} \text {, BG2 } 510 \mathrm{~nm} \text { and } \\
\text { BG3 } 480 \mathrm{~nm}\end{array}$ & [180] \\
\hline $\begin{array}{c}55 \mathrm{SiO}_{2}-15 \mathrm{CaO}-10 \mathrm{P}_{2} \mathrm{O}_{5^{-}} \\
10 \mathrm{~K}_{2} \mathrm{O}-5 \mathrm{MgO}-5 \mathrm{Na}_{2} \mathrm{O}\end{array}$ & Ti6Al7Nb & RF-MS & $\begin{array}{l}\text { Coatings with homogeneous and } \\
\text { defect free surface. Thickness } \\
\text { 750-980 nm }\end{array}$ & [181] \\
\hline HABG, HA & $\begin{array}{l}\text { Titanium } \\
\text { Biocomp }{ }^{\circledR}\end{array}$ & RF-MS & $\begin{array}{c}\text { Thickness } 2 \mu \mathrm{m} \text {; roughness } \\
1.2-1.5 \mu \mathrm{m}\end{array}$ & [185] \\
\hline BGS53P4, HA & $\begin{array}{l}\text { Titanium } \\
\text { Biocomp }^{\circledR}\end{array}$ & RF-MS & $\begin{array}{l}\text { Thickness } 0.6-3 \mu \mathrm{m} \text {; surface } \\
\text { roughness } 1.5-2.1 \mu \mathrm{m}\end{array}$ & [186] \\
\hline $\mathrm{T} 1$ & Ti6Al4V & RF-MS & $\begin{array}{l}\text { Amorphous coatings. thickness } \\
\qquad 1.7-3 \mu \mathrm{m}\end{array}$ & [187] \\
\hline
\end{tabular}

\section{Conclusions, Challenges and Future Perspectives}

Various coating techniques and variants-that can be employed to realize bioactive glass coatings-exist; each of them has its advantages and disadvantages. The choice of the coating technique strongly depends on the nature of the bioactive glass, and on the specific nature of biomedical device to be coated, because different features are required for each application. For instance, some orthopaedic screws must be explanted, while a stem in a hip prosthesis is expected to last a lifetime. For these reasons, it is not simple to determine which is the better coating technique to realize bioactive glass coatings. Among the available coating techniques, the plasma spraying technique is the only one used in industry to produce bioactive coatings on flat biomaterials substrates. Unfortunately, the long-term stability of bioactive glass coatings deposited by plasma spraying techniques is not satisfactory yet; therefore, investigations to improve the features of coatings are ongoing. The liquid feedstock-based techniques such as HVSFS, SPS and SPPS can be employed to realize coatings starting from smaller particles size, compared to conventional thermal spraying processes. On the other hand, thin and adherent coatings can be produced by physical vapour deposition (PVD), such as pulsed laser deposition (PLD) and pulsed electron deposition (PED), and radio-frequency magnetron sputtering (RF-MS). Moreover, electrophoretic deposition and coatings techniques based on sol-gel can realize coatings on complex shaped substrates. Both these techniques allow the creation of multi layered systems, and the control of the coatings' thickness is simple. Furthermore, the sol-gel technique allows the use of a wide range of compositions of bioactive glasses that are not supported in conventional techniques, with the advantage of low temperature treatment. From this point of view, laser cladding is also interesting because it does not imply high temperature heat treatment. In this way, the microstructure of the substrate is maintained. On the contrary, the enamelling technique uses a high temperature heat treatment which can damage the substrate; however, this technique is still widely used, because of the simplicity of its process and low cost. 
The increasing need for biomedical devices is driving research on the study of deposition techniques and the optimization of spraying parameters of coating techniques to assess the available ones. However, the main direction of investigations should be on the achievement of better understanding of bioactive glass compositions, also in terms of the effects of doping elements. Bioactive glasses can be produced with certain compositions able to enhance a specific response in the host or to introduce antibacterial properties. Bioactive glass compositions could be tailored depending on the specific deposition techniques adopted, to obtain well adherent coatings and to reduce failure. In this regard, bioactive glass coatings present a great advantage compared to ceramic coatings, such as hydroxyapatite or calcium phosphates, because bioactive glass compositions can be easily tuned. A smart design of bioactive glasses could result in the development of bioactive glasses with a large processing window. In fact, bioactive glasses with large processing windows could be optimally employed for the deposition of fully amorphous coatings by thermal spraying techniques. In the authors' opinion, this is one of the major challenges for the development of the next generation coatings. Generally, $\mathrm{MgO}$ and $\mathrm{SrO}$ oxides are introduced in bioactive glass compositions, to increase the crystallization temperature, and thus to obtain bioactive glasses with low tendency to devitrification during heat treatment $[98,188]$. For instance, a new generation of bioactive glasses with ultra-high crystallization temperature [188-196] could be advantageously employed to produce completely amorphous bioactive glass coatings, with a proper selection of the processing technique and optimization of spraying parameters. Moreover, such novel bioactive glasses have shown to improve cell proliferation; Sr and Mg ions are known to enhance the replication of preosteoblastic cells $[197,198]$, as well as cells proliferation and angiogenesis $[199,200]$. Furthermore, the addition of ions with antibacterial effects such as $\mathrm{Ag}, \mathrm{Cu}, \mathrm{Zn}$ would be advantageous during and after implantations because of the releasing of such ions at the site of implant. It is to be noted that the introduction of ions with antibacterial effects require further investigations as antibacterial tests in addition to cells tests and bioactivity tests. However, this could be a substantial improvement in the state-of-the-art for achieving multi-functional bioactive coatings.

Future work should be focused on the investigation of the optimal combination of deposition techniques, spraying parameters, and bioglass compositions that could be employed for the realisation of optimized multi-functional coatings, able to promote tissue healing and regeneration and to the guarantee long term stability and duration of implants.

Finally, it is worth noting that the bioactivity of coatings has been widely investigated by immersion in SBF solution. On the contrary, in vitro and in vivo tests on metallic implants coated by bioactive glasses are still limited. The investigation of potential cytotoxicity and biocompatibility of coatings by in vitro tests and, more importantly, preclinical studies in animal models should be significantly increased. Furthermore, research on stability over time and long-term properties should be fundamental, because it permits one to investigate the response of implants once implanted in the human body [27], which is a complex and dynamic environment. This should be one of the most important goals for the future.

Author Contributions: Investigation, R.S. and D.B.; conceptualization, V.C.; writing-original draft preparation, R.S. and D.B.; writing-review and editing, V.C.; supervision, V.C. All authors have read and agreed to the published version of the manuscript.

Funding: This research received no external funding.

Conflicts of Interest: The authors declare no conflict of interest.

\section{References}

1. Saini, M. Implant biomaterials: A comprehensive review. World J. Clin. Cases 2015, 3, 52. [CrossRef] [PubMed]

2. Niinomi, M. Metals for Biomedical Devices; Woodhead Publishing Limited: Cambridge, UK, 2010; pp. 1-405.

3. Liu, X.; Chu, P.K.; Ding, C. Surface modification of titanium, titanium alloys, and related materials for biomedical applications. Mater. Sci. Eng. R 2005, 47, 49-121. [CrossRef] 
4. Henao, J.; Poblano-salas, C.; Monsalve, M.; Corona-Castuera, J. Bio-active glass coatings manufactured by thermal spray: A status report. Integr. Med. Res. 2019, 8, 4965-4984. [CrossRef]

5. Ratner, B.; Hoffman, A.; Schoen, F.; Lemons, J. Biomaterials Science an Introduction to Materials in Medicine, 2nd ed.; Elsevier: Amsterdam, The Netherlands, 2004; pp. 1-851.

6. García, C.; Ceré, S.; Durán, A. Bioactive coatings prepared by sol-gel on stainless steel 316L. J. Non-Cryst. Solids 2004, 348, 218-224. [CrossRef]

7. Pourhashem, S.; Afshar, A. Double layer bioglass-silica coatings on 316L stainless steel by sol-gel method. Ceram. Int. 2014, 40, 993-1000. [CrossRef]

8. Fathi, M.H.; Doostmohammadi, A. Bioactive glass nanopowder and bioglass coating for biocompatibility improvement of metallic implant. J. Mater. Process. Technol. 2009, 209, 1385-1391. [CrossRef]

9. Blackwood, D.J. Biomaterials: Past successes and future problems. Corros. Rev. 2003, 21, 97-124. [CrossRef]

10. Hanawa, T. Metal ion release from metal implants. Mater. Sci. Eng. C 2004, 24, 745-752. [CrossRef]

11. Rojaee, R.; Fathi, M.; Raeissi, K.; Taherian, M. Electrophoretic deposition of bioactive glass nanopowders on magnesium based alloy for biomedical applications. Ceram. Int. 2014, 40, 7879-7888. [CrossRef]

12. Witte, F.; Hort, N.; Vogt, C.; Cohen, S.; Kainer, K.U.; Willumeit, R. Degradable biomaterials based on magnesium corrosion. Curr. Opin. Solid State Mater. Sci. 2008, 12, 63-72. [CrossRef]

13. Jones, J.; Clare, A. Bio-Glasses an Introduction; John Wiley and Sons Ltd.: Cambridge, UK, 2012; pp. 1-235.

14. Fathi, M.H.; Doost Mohammadi, A. Preparation and characterization of sol-gel bioactive glass coating for improvement of biocompatibility of human body implant. Mater. Sci. Eng. A 2008, 474, 128-133. [CrossRef]

15. Galliano, P.; De Damborenea, J.J.; Pascual, M.J.; Durán, A. Sol-Gel coatings on 316L steel for clinical applications. J. Sol-Gel Sci. Technol. 1998, 13, 723-727. [CrossRef]

16. Moskalewicz, T.; Seuss, S.; Boccaccini, A.R. Microstructure and properties of composite polyetheretherketone/ Bioglass ${ }^{\circledR}$ coatings deposited on Ti-6Al-7Nb alloy for medical applications. Appl. Surf. Sci. 2013, 273, 62-67. [CrossRef]

17. Niu, S.; Cai, S.; Liu, T.; Zhao, H.; Wang, X.; Ren, M. 45 S5 bioactive glass-ceramic coated magnesium alloy with strong interfacial bonding strength by "superplasticity diffusion bonding". Mater. Lett. 2015, 141, 96-99. [CrossRef]

18. Teghil, R.; D'Alessio, L.; Ferro, D.; Barinov, S.M. Hardness of bioactive glass film deposited on titanium alloy by pulsed laser ablation. J. Mater. Sci. Lett. 2002, 21, 379-382. [CrossRef]

19. Cannillo, V.; Colmenares-Angulo, J.; Lusvarghi, L.; Pierli, F.; Sampath, S. In vitro characterisation of plasma-sprayed apatite/wollastonite glass-Ceramic biocoatings on titanium alloys. J. Eur. Ceram. Soc. 2009, 29, 1665-1677. [CrossRef]

20. Sun, L.; Berndt, C.C.; Gross, K.A.; Kucuk, A. Material fundamentals and clinical performance of plasmasprayed hydroxyapatite coatings: A review. Keynes Post-Keynes. Polit. Econ. 1999, 58, 570-592. [CrossRef]

21. Harun, W.S.W.; Asri, R.I.M.; Alias, J.; Zulkifli, F.H.; Kadirgama, K.; Ghani, S.A.C. A comprehensive review of hydroxyapatite-based coatings adhesion on metallic biomaterials. Ceram. Int. 2018, 44, 1250-1268. [CrossRef]

22. Nagano, M.; Nakamura, T.; Kokubo, T.; Tanahashi, M.; Ogawas, M. Differences of bone bonding ability and degradation behaviour in vivo between amorphous calcium phosphate and highly crystalline hydroxyapatite coating. Biomaterials 1996, 17, 1771-1777. [CrossRef]

23. Lin, D.; Wang, X. A novel method to synthesize hydroxyapatite coating with hierarchical structure. Colloids Surf. B Biointerfaces 2011, 82, 637-640. [CrossRef]

24. Haider, A.; Haider, S.; Han, S.S.; Kang, I.K. Recent advances in the synthesis, functionalization and biomedical applications of hydroxyapatite: A review. RSC Adv. 2017, 7, 7442-7458. [CrossRef]

25. Kweh, S.W.K.; Khor, K.A.; Cheang, P. An in vitro investigation of plasma sprayed hydroxyapatite (HA) coatings produced with flame-spheroidized feedstock. Biomaterials 2002, 23, 775-785. [CrossRef]

26. Cattini, A.; Bellucci, D.; Sola, A.; Paw, L.; Cannillo, V. Suspension plasma spraying of optimised functionally graded coatings of bioactive glass/hydroxyapatite. Surf. Coat. Technol. 2013, 236, 118-126. [CrossRef]

27. Brunello, G.; Elsayed, H.; Biasetto, L. Bioactive glass and silicate-based ceramic coatings on metallic implants: Open challenge or outdated topic? Materials 2019, 12, 2929. [CrossRef] [PubMed]

28. Elsayed, H.; Brunello, G.; Gardin, C.; Ferroni, L.; Badocco, D.; Pastore, P. Bioactive sphene-based ceramic coatings on cpTi substrates for dental implants: An in vitro study. Materials 2018, 11, 2234. [CrossRef] [PubMed] 
29. Cannillo, V.; Lusvarghi, L.; Sola, A. Production and characterization of plasma-sprayed $\mathrm{TiO}_{2}-$ hydroxyapatite functionally graded coatings. J. Eur. Ceram. Soc. 2008, 28, 2161-2169. [CrossRef]

30. Cannillo, V.; Manfredini, T.; Montorsi, M.; Siligardi, C.; Sola, A. Microstructure-based modelling and experimental investigation of crack propagation in glass-alumina functionally graded materials. J. Eur. Ceram. Soc. 2006, 26, 3067-3073. [CrossRef]

31. Ylänen, H. Bioactive Glasses Materials, Properties and Applications, 2nd ed.; Woodhead Publishing: Cambridge, UK, 2018; pp. 1-407.

32. Jones, J.R. Reprint of: Review of bioactive glass: From hench to hybrids. Acta Biomater. 2015, 23, S53-S82. [CrossRef]

33. Wen, L.; Rüssel, C.; Day, D.E.; Völksch, G. Bioactive comparison of a borate, phosphate and silicate glass. J. Mater. Res. 2006, 21, 125-131.

34. Cañas, E.; Vicent, M.; Bannier, E.; Carpio, P.; Orts, M.J.; Sánchez, E. Effect of particle size on processing of bioactive glass powder for atmospheric plasma spraying. J. Eur. Ceram. Soc. 2016, 36, 837-845. [CrossRef]

35. Balamurugan, A.; Balossier, G.; Michel, J.; Ferreira, J.M.F. Electrochemical and structural evaluation of functionally graded bioglass-apatite composites electrophoretically deposited onto $\mathrm{Ti}_{6} \mathrm{Al}_{4} \mathrm{~V}$ alloy. Electrochim. Acta 2009, 54, 1192-1198. [CrossRef]

36. Sola, A.; Bellucci, D.; Cannillo, V.; Cattini, A. Bioactive glass coatings: A review. Surf. Eng. 2011, $27,560-572$. [CrossRef]

37. Pawlowski, L. The Science and Engineering of Thermal Spray Coatings; John Wiley \& Sons Inc.: New York, NY, USA, 2008; pp. 1-597.

38. Dorfman, M.R. Thermal Spray Coatings. In Handbook of Environmental Degradation of Materials, 2nd ed.; Elsevier Inc.: Philadelphia, PA, USA, 2012; pp. 569-596.

39. Gabbi, C.; Cacchioli, A. Bioactive glass coating: Physicochemical aspects and biological findings. Biomaterials 1995, 16, 515-520. [CrossRef]

40. Lee, T.M.; Chang, E.; Wang, B.C.; Yang, C.Y. Characteristics of plasma-sprayed bioactive glass coatings on Ti-6A1-4V alloy: An in vitro study. Surf. Coat. Technol. 1996, 79, 170-177. [CrossRef]

41. Sun, L. Thermal spray coatings on orthopedic devices: When and how the fda reviews your coatings. J. Therm. Spray Technol. 2018, 27, 1280-1290. [CrossRef]

42. Lindgren, V.; Vp, G.; Nebergall, A.; Me, G.; Rolfson, O.; Malchau, H. Radiographic and clinical outcomes of porous titanium-coated and plasma-sprayed acetabular shells. J. Bone Jt. Surg. 2018, 100, 1673-1681. [CrossRef]

43. Herman, H.; Sampath, S.; Mccune, R. Thermal spray: Current status and future trends. MRS Bull. 2000, 25, 17-25. [CrossRef]

44. Verné, E.; Bretcanu, O.; Balagna, C. Early stage reactivity and in vitro behavior of silica-based bioactive glasses and glass-ceramics. J. Mater. Sci. Mater. Med. 2009, 20, 75-87. [CrossRef]

45. El-ghannam, A.; Hamazawy, E.; Yehia, A. Effect of thermal treatment on bioactive glass microstructure, corrosion behavior, $\zeta$ potential, and protein adsorption. J. Biomed. Mater. Res. 2001, 55, 387-395. [CrossRef]

46. Marghussian, V.K.; Sheikh-Mehdi Mesgar, A. Effects of composition on crystallization behaviour and mechanical properties of bioactive glass-ceramics in the $\mathrm{MgO}-\mathrm{CaO}-\mathrm{SiO}_{2}-\mathrm{P}_{2} \mathrm{O}_{5}$ system. Ceram. Int. 2000, 26, 415-420. [CrossRef]

47. Boccaccini, A.R.; Brauer, D.S.; Hupa, L. Bioactive Glasses Fundamentals, Technology and Applications; Aldo, R., Delia, S., Brauer, L.H., Eds.; Royal Society of Chemistry: London, UK, 2017; pp. 1-530.

48. Lopez-esteban, S.; Saiz, E.; Fujino, S.; Oku, T.; Suganuma, K.; Tomsia, A.P. Bioactive glass coatings for orthopedic metallic implants. J. Eur. Ceram. Soc. 2003, 23, 2921-2930. [CrossRef]

49. Vanderstraeten, J.; Schrooten, J.; Timmermans, G.; Braun, E. Glasses and bioglasses: Synthesis and coatings. J. Eur. Ceram. Soc. 1997, 17, 147-152.

50. Mauer, G.; Vaen, R.; Stöver, D. Plasma and particle temperature measurements in thermal spray: Approaches and applications. J. Therm. Spray Technol. 2011, 20, 391-406. [CrossRef]

51. Monsalve, M.; Ageorges, H.; Lopez, E.; Vargas, F.; Bolivar, F. Bioactivity and mechanical properties of plasma-sprayed coatings of bioglass powders. Surf. Coat. Technol. 2013, 220, 60-66. [CrossRef]

52. Fauchais, L.P.; Heberlein, V.R.J.; Boulos, I.M. Thermal Spray Fundamentals from Powder to Part. Metallurgical Transactions B; Springer: New York, NY, USA, 2014; Volume 15, pp. 1-1545. 
53. Goller, G. The effect of bond coat on mechanical properties of plasma sprayed bioglass-titanium coatings. Ceram. Int. 2004, 30, 351-355. [CrossRef]

54. Peitl, O.; Federal, U.; Peitl, O. Effect of crystallization on apatite-layer formation of bioactive glass $45 \mathrm{~S} 5$. J. Biomed. Mater. Res. 1996, 30, 509-514.

55. Jallot, E.; Benhayoune, H.; Kilian, L.; Irigaray, J.L.; Barbotteau, Y.; Balossier, G. Dissolution kinetics, selective leaching, and interfacial reactions of a bioglass coating enriched in alumina. J. Colloid Interface Sci. 2001, 233, 83-90. [CrossRef]

56. Popa, A.C.; Marques, V.M.F.; Stan, G.E.; Husanu, M.A.; Galca, A.C.; Ghica, C. Nanomechanical characterization of bioglass films synthesized by magnetron sputtering. Thin Solid Films 2014, 553, 166-172. [CrossRef]

57. Kristensen, H.G. Particle agglomeration. Adv. Pharm. Sci. 1995, 7, 221-272.

58. Calvo, V.; Cabedo, M.; Bannier, E.; Recacha, E.; Boccaccini, A.; Aria, L. $45 \mathrm{~S} 5$ bioactive glass coatings by atmospheric plasma spraying obtained from feedstocks prepared by different routes. J. Mater. Sci. 2014, 49, 7933-7942. [CrossRef]

59. Vicent, M.; Sánchez, E.; Mallol, G.; Moreno, R. Study of colloidal behaviour and rheology of Al2O 3-TiO2 nanosuspensions to obtain free-flowing spray-dried granules for atmospheric plasma spraying. Ceram. Int. 2013, 39, 8103-8111. [CrossRef]

60. Poirier, T.; Planche, M.P.; Landemarre, O.; Coddet, C. Particles spreading phenomena in the case of glass thermal spraying. J. Therm. Spray Technol. 2008, 17, 564-573. [CrossRef]

61. Cattini, A.; Łatka, L.; Bellucci, D.; Bolelli, G.; Sola, A.; Lusvarghi, L. Suspension plasma sprayed bioactive glass coatings: Effects of processing on microstructure, mechanical properties and in-vitro behaviour. Surf. Coat. Technol. 2013, 220, 52-59. [CrossRef]

62. Hench, L.L.; Polak, J.M. Third-generation biomedical materials. Science 2002, 295, 1014-1017. [CrossRef] [PubMed]

63. Carvalho, F.L.S.; Borges, C.S.; Branco, J.R.T.; Pereira, M.M. Structural analysis of hydroxyapatite/bioactive glass composite coatings obtained by plasma spray processing. J. Non-Cryst. Solids 1999, 247, 64-68. [CrossRef]

64. Chern Lin, J.H.; Lin, H.J.; Ding, S.J.; Ju, C.P. Characterization of immersed hydroxyapatite-bioactive glass coatings in Hank's solution. Mater. Chem. Phys. 2000, 64, 229-240. [CrossRef]

65. Andersson, H.; Kangasniemi, I. Calcium phosphate formation at the surface of bioactive glass in vitro. J. Biomed. Mater. Res. 1991, 25, 1019-1030. [CrossRef]

66. Newman, S.D.; Lotfibakhshaiesh, N.; Donnell, M.O.; Walboomers, X.F.; Horwood, N.; Jansen, J.A. Enhanced osseous implant fixation with strontium-substituted bioactive glass coating. Tissue Eng. Part A 2014, 20, 1850-1857. [CrossRef]

67. Pawlowski, L. Suspension and solution thermal spray coatings. Surf. Coat. Technol. 2009, 203, $2807-2829$. [CrossRef]

68. Cañas, E.; Vicent, M.; Orts, M.J.; Moreno, R.; Sánchez, E. Bioactive glass suspensions preparation for suspension plasma spraying. J. Eur. Ceram. Soc. 2016, 36, 4281-4290. [CrossRef]

69. Otterstedt, J.-E.; Brandreth, D.A. Small Particles and Technology; Springer Science + Business Media LLC: New York, NY, USA, 1998; pp. 1-519.

70. Goodwin, J. Colloids and Interfaces with Surfractants and Polymers an Introduction; John Wiley \& Sons Ltd.: London, UK, 2004; pp. 1-281.

71. Killinger, A.; Kuhn, M.; Gadow, R. High-velocity suspension flame spraying (HVSFS), a new approach for spraying nanoparticles with hypersonic speed. Surf. Coat. Technol. 2006, 201, 1922-1929. [CrossRef]

72. Bolelli, G.; Stiegler, N.; Bellucci, D.; Cannillo, V.; Gadow, R.; Killinger, A. Deposition mechanisms in high velocity suspension spraying: Case study for two bioactive materials. Surf. Coat. Technol. 2012, 210, $28-45$. [CrossRef]

73. Bolelli, G.; Rauch, J.; Cannillo, V.; Killinger, A.; Lusvarghi, L.; Gadow, R. Investigation of high-velocity suspension flame sprayed (HVSFS) glass coatings. Mater. Lett. 2008, 62, 2772-2775. [CrossRef]

74. Altomare, L.; Bellucci, D.; Bolelli, G.; Bonferroni, B.; Cannillo, V.; De Nardo, L. Microstructure and in vitro behaviour of $45 \mathrm{~S} 5$ bioglass coatings deposited by high velocity suspension flame spraying (HVSFS). J. Mater. Sci. Mater. Med. 2011, 22, 1303-1319. [CrossRef] 
75. Kaßner, H.; Vaßen, R.; Stöver, D. Study on instant droplet and particle stages during suspension plasma spraying (SPS). Surf. Coat. Technol. 2008, 202, 4355-4361.

76. Bolelli, G.; Cannillo, V.; Gadow, R.; Killinger, A.; Lusvarghi, L.; Rauch, J. Effect of the suspension composition on the microstructural properties of high velocity suspension flame sprayed (HVSFS) $\mathrm{Al}_{2} \mathrm{O}_{3}$ coatings. Surf. Coat. Technol. 2010, 204, 1163-1179. [CrossRef]

77. Dongmo, E.; Wenzelburger, M.; Gadow, R. Analysis and optimization of the HVOF process by combined experimental and numerical approaches. Surf. Coat. Technol. 2008, 202, 4470-4478. [CrossRef]

78. Bolelli, G.; Cannillo, V.; Gadow, R.; Killinger, A.; Lusvarghi, L.; Sola, A. Microstructure and in-vitro behaviour of a novel high velocity suspension flame sprayed (HVSFS) bioactive glass coating. Surf. Coat. Technol. 2010, 205, 1145-1149. [CrossRef]

79. Bolelli, G.; Cannillo, V.; Gadow, R.; Killinger, A.; Lusvarghi, L.; Rauch, J. Microstructural and in vitro characterisation of high-velocity suspension flame sprayed (HVSFS) bioactive glass coatings. J. Eur. Ceram. Soc. 2009, 29, 2249-2257. [CrossRef]

80. Bellucci, D.; Bolelli, G.; Cannillo, V.; Gadow, R.; Killinger, A.; Lusvarghi, L. High velocity suspension flame sprayed (HVSFS) potassium-based bioactive glass coatings with and without $\mathrm{TiO}_{2}$ bond coat. Surf. Coat. Technol. 2012, 206, 3857-3868. [CrossRef]

81. Bellucci, D.; Cannillo, V.; Ciardelli, G.; Gentile, P.; Sola, A. Potassium based bioactive glass for bone tissue engineering. Ceram. Int. 2010, 36, 2449-2453. [CrossRef]

82. Bellucci, D.; Cannillo, V.; Sola, A. A new potassium-based bioactive glass: Sintering behaviour and possible applications for bioceramic scaffolds. Ceram. Int. 2011, 37, 145-157. [CrossRef]

83. Díaz, L.A.; Cabal, B.; Prado, C.; Moya, J.S.; Torrecillas, R.; Fernández, A. High-velocity suspension flame sprayed (HVSFS) soda-lime glass coating on titanium substrate: Its bactericidal behaviour. J. Eur. Ceram. Soc. 2016, 36, 2653-2658. [CrossRef]

84. Bolelli, G.; Bellucci, D.; Cannillo, V.; Gadow, R.; Killinger, A.; Lusvarghi, L. Comparison between suspension plasma sprayed and high velocity suspension flame sprayed bioactive coatings. Surf. Coat. Technol. 2015, 280, 232-249. [CrossRef]

85. Zhang, S.L.; Li, C.X.; Li, C.J. Chemical compatibility and properties of suspension plasma-sprayed $\mathrm{SrTiO}_{3}$-based anodes for intermediate-temperature solid oxide fuel cells. J. Power Sources 2014, 264, 195-205. [CrossRef]

86. Ganvir, A.; Curry, N.; Markocsan, N.; Nylén, P.; Toma, F.L. Comparative study of suspension plasma sprayed and suspension high velocity oxy-fuel sprayed YSZ thermal barrier coatings. Surf. Coat. Technol. 2015, 268, 70-76. [CrossRef]

87. Fauchais, P.; Vardelle, M.; Vardelle, A.; Goutier, S. What Do We Know, What are the current limitations of suspension plasma spraying? J. Therm. Spray Technol. 2015, 24, 1120-1129. [CrossRef]

88. Moreno, R.; Bannier, E. Feedstock Suspensions and Solutions Future Development of Thermal Spray Coatings: Types, Designs, Manufacture and Applications; Elsevier Ltd.: Amsterdam, The Netherlands, 2015; pp. 51-80.

89. Cañas, E.; Vicent, M.; Orts, M.J.; Sánchez, E. Bioactive glass coatings by suspension plasma spraying from glycolether-based solvent feedstock. Surf. Coat. Technol. 2017, 318, 190-197. [CrossRef]

90. Cattini, A.; Bellucci, D.; Sola, A.; Pawlowski, L.; Cannillo, V. Functional bioactive glass topcoats on hydroxyapatite coatings: Analysis of microstructure and in-vitro bioactivity. Surf. Coat. Technol. 2014, 240, 110-117. [CrossRef]

91. Cattini, A.; Bellucci, D.; Sola, A.; Pawłowski, L.; Cannillo, V. Microstructural design of functionally graded coatings composed of suspension plasma sprayed hydroxyapatite and bioactive glass. J. Biomed. Mater. Res. Part B 2013, 102, 551-560. [CrossRef]

92. Killinger, A.; Gadow, R.; Mauer, G.; Guignard, A.; Vaßen, R.; Stover, D. Review of new developments in suspension and solution precursor thermal spray processes. ASM Int. 2011, 20, 677-695. [CrossRef]

93. Cañas, E.; Orts, M.J.; Boccaccini, A.R.; Sánchez, E. Solution precursor plasma spraying (SPPS): A novel and simple process to obtain bioactive glass coatings. Mater. Lett. 2018, 223, 198-202. [CrossRef]

94. Candidato, R.T.; Sokołowski, P.; Pawłowski, L.; Lecomte-Nana, G.; Constantinescu, C.; Denoirjean, A. Development of hydroxyapatite coatings by solution precursor plasma spray process and their microstructural characterization. Surf. Coat. Technol. 2017, 318, 39-49. [CrossRef]

95. Gell, M.; Jordan, E.H.; Teicholz, M.; Cetegen, B.M.; Padture, N.P.; Xie, L. Thermal barrier coatings made by the solution precursor plasma spray process. ASM Int. 2008, 17, 124-135. [CrossRef] 
96. Yu, Z.; Moussa, H.; Liu, M.; Schneider, R.; Moliere, M.; Liao, H. Solution precursor plasma spray process as an alternative rapid one-step route for the development of hierarchical $\mathrm{ZnO}$ fi lms for improved photocatalytic degradation. Ceram. Int. 2018, 44, 2085-2092. [CrossRef]

97. Cañas, E.; Orts, M.J.; Boccaccini, A.R.; Sánchez, E. Microstructural and in vitro characterization of $45 S 5$ bioactive glass coatings deposited by solution precursor plasma spraying (SPPS). Surf. Coat. Technol. 2019, 371, 151-160. [CrossRef]

98. Monsalve, M.; Lopez, E.; Ageorges, H.; Vargas, F. Bioactivity and mechanical properties of bioactive glass coatings fabricated by flame spraying. Surf. Coat. Technol. 2015, 268, 142-146. [CrossRef]

99. Moridi, A.; Hassani-Gangaraj, S.M.; Guagliano, M.; Dao, M. Cold spray coating: Review of material systems and future perspectives. Surf. Eng. 2014, 30, 369-395. [CrossRef]

100. Grigoriev, S.; Okunkova, A.; Sova, A.; Bertrand, P.; Smurov, I. Cold spraying: From process fundamentals towards advanced applications. Surf. Coat. Technol. 2015, 268, 77-84. [CrossRef]

101. Vilardell, A.M.; Cinca, N.; Concustell, A.; Dosta, S.; Cano, I.G.; Guilemany, J.M. Cold spray as an emerging technology for biocompatible and antibacterial coatings: State of art. J. Mater. Sci. 2015, 50, 4441-4462. [CrossRef]

102. Cannillo, V.; Sola, A. Different approaches to produce coatings with bioactive glasses: Enamelling vs. plasma spraying. J. Eur. Ceram. Soc. 2010, 30, 2031-2039. [CrossRef]

103. Ferraris, M.; Verné, E.; Appendino, P.; Moisescu, C.; Krajewski, A.; Ravaglioli, A. Coatings on zirconia for medical applications. Biomaterials 2000, 21, 765-773. [CrossRef]

104. Bosetti, M.; Vernè, E.; Ferraris, M.; Ravaglioli, A.; Cannas, M. In vitro characterisation of zirconia coated by bioactive glass. Biomaterials 2001, 22, 987-994. [CrossRef]

105. Kim, C.Y.; Jee, S.S. Hydroxyapatite formation on bioactive-glazed alumina. J. Eur. Ceram. Soc. 2003, 23, 1803-1811. [CrossRef]

106. Martorana, S.; Fedele, A.; Mazzocchi, M.; Bellosi, A. Surface coatings of bioactive glasses on high strength ceramic composites. Appl. Surf. Sci. 2009, 255, 6679-6685. [CrossRef]

107. Vitale-Brovarone, C.; Verné, E. $\mathrm{SiO}_{2}-\mathrm{CaO}-\mathrm{K}_{2} \mathrm{O}$ coatings on alumina and Ti6Al4V substrates for biomedical applications. J. Mater. Sci. Mater. Med. 2005, 16, 863-871. [CrossRef] [PubMed]

108. Bellucci, D.; Sola, A.; Salvatori, R.; Anesi, A.; Chiarini, L.; Cannillo, V. Sol-gel derived bioactive glasses with low tendency to crystallize: Synthesis, post-sintering bioactivity and possible application for the production of porous scaffolds. Mater. Sci. Eng. C 2014, 43, 573-586. [CrossRef]

109. Bellucci, D.; Sola, A.; Cannillo, V. Low temperature sintering of innovative bioactive glasses. J. Am. Ceram. Soc. 2012, 95, 1313-1319. [CrossRef]

110. Bellucci, D.; Sola, A.; Salvatori, R.; Anesi, A.; Chiarini, L.; Cannillo, V. Role of magnesium oxide and strontium oxide as modifiers in silicate-based bioactive glasses: Effects on thermal behaviour, mechanical properties and in-vitro bioactivity. Mater. Sci. Eng. C 2017, 72, 566-575. [CrossRef]

111. Matinmanesh, A.; Li, Y.; Nouhi, A.; Zalzal, P.; Schemitsch, E.H.; Towler, M.R. Evaluating the critical strain energy release rate of bioactive glass coatings on $\mathrm{Ti}_{6} \mathrm{Al}_{4} \mathrm{~V}$ substrates after degradation. J. Mech. Behav. Biomed. Mater. 2018, 78, 273-281. [CrossRef]

112. Sola, A.; Bellucci, D.; Cannillo, V. Enamelled coatings produced with low-alkaline bioactive glasses. Surf. Coat. Technol. 2014, 248, 1-8. [CrossRef]

113. Hench, L.L.; Paschall, H.A. Direct chemical bond of bioactive glass-ceramic materials to bone and muscle. J. Biomed. Mater. Res. 1973, 7, 25-42. [CrossRef] [PubMed]

114. Wang, Y.Y.; Li, C.J.; Ohmori, A. Influence of substrate roughness on the bonding mechanisms of high velocity oxy-fuel sprayed coatings. Thin Solid Films 2005, 485, 141-147. [CrossRef]

115. Gomez-Vega, J.M.; Saiz, E.; Tomsia, A.P.; Marshall, G.W.; Marshall, S.J. Bioactive glass coatings with hydroxyapatite and Bioglass ${ }^{\circledR}$ particles on Ti-based implants. 1. Processing. Biomaterials 2000, 21, 105-111. [CrossRef]

116. Cannillo, V.; Montorsi, M.; Siligardi, C.; Sola, A.; de Portu, G.; Micele, L. Microscale computational simulation and experimental measurement of thermal residual stresses in glass-alumina functionally graded materials. J. Eur. Ceram. Soc. 2006, 26, 1411-1419. [CrossRef]

117. Kim, C.Y.; Jung, W.L. Surface bio-modification of titanium implants by an enamel process. J. Ceram. Process. Res. 2005, 6, 338-344. 
118. Fujino, S.; Tokunaga, H.; Hata, S.; Saiz, E.; Tomsia, A.P. Graded glass coatings for Co-Cr implant alloys. J. Mater. Sci. 2005, 40, 2499-2503. [CrossRef]

119. Li, Y.; Matinmanesh, A.; Curran, D.J.; Schemitsch, E.H.; Zalzal, P.; Papini, M. Characterization and fracture property of different strontium-containing borate-based glass coatings for $\mathrm{Ti}_{6} \mathrm{Al}_{4} \mathrm{~V}$ substrates. J. Non-Cryst. Solids 2017, 458, 69-75. [CrossRef]

120. Rodriguez, O.; Matinmanesh, A.; Phull, S.; Schemitsch, E.; Zalzal, P.; Clarkin, O. Silica-based and borate-based, titania-containing bioactive coatings characterization: Critical strain energy release rate, residual stresses, hardness, and thermal expansion. J. Funct. Biomater. 2016, 7, 32. [CrossRef]

121. Nychka, J.A.; Mazur, S.L.R.; Kashyap, S.; Li, D.; Yang, F. Dissolution of bioactive glasses: The effects of crystallinity coupled with stress. JOM 2009, 61, 45-51. [CrossRef]

122. Tang, C.Y.; Tsui, C.P.; Janackovic, D.J.; Uskokovic, P.S. Nanomechanical properties evaluation of bioactive glass coatings on titanium alloy substrate. J. Optoelectron Adv. Mater. 2006, 8, 1194-1199.

123. Matinmanesh, A.; Rodriguez, O.; Towler, M.R.; Zalzal, P.; Schemitsch, E.H.; Papini, M. Quantitative evaluation of the adhesion of bioactive glasses onto $\mathrm{Ti}_{6} \mathrm{Al}_{4} \mathrm{~V}$ substrates. Mater. Des. 2016, 97, 213-221. [CrossRef]

124. Foppiano, S.; Marshall, S.J.; Marshall, G.W.; Saiz, E.; Tomsia, A.P. Bioactive glass coatings affect the behavior of osteoblast-like cells. Acta Biomater. 2007, 3, 765-771. [CrossRef] [PubMed]

125. Foppiano, S.; Marshall, S.J.; Saiz, E.; Tomsia, A.P.; Marshall, G.W. Functionally graded bioactive coatings: Reproducibility and stability of the coating under cell culture conditions. Acta Biomater. 2006, 2, 133-142. [CrossRef] [PubMed]

126. Almeida, R.M.; Gama, A.; Vueva, Y. Bioactive sol-gel scaffolds with dual porosity for tissue engineering. J. Sol-Gel Sci. Technol. 2011, 57, 336-342. [CrossRef]

127. Furkó, M.; Balázsi, K.; Balázsi, C. Comparative study on preparation and characterization of bioactive coatings for biomedical applications-A review on recent patents and literature. Rev. Adv. Mater. Sci. 2017, $48,25-51$.

128. Durán, A.; Conde, A.; Gómez Coedo, A.; Dorado, T.; García, C.; Ceré, S. Sol-gel coatings for protection and bioactivation of metals used in orthopaedic devices. J. Mater. Chem. 2004, 14, 2282-2290. [CrossRef]

129. Metikoš-Huković, M.; Kwokal, A.; Piljac, J. The influence of niobium and vanadium on passivity of titanium-based implants in physiological solution. Biomaterials 2003, 24, 3765-3775. [CrossRef]

130. Singh, R.; Dahotre, N.B. Corrosion degradation and prevention by surface modification of biometallic materials. J. Mater. Sci. Mater. Med. 2007, 18, 725-751. [CrossRef]

131. Balamurugan, A.; Rajeswari, S.; Balossier, G.; Rebelo, A.H.S.; Ferreira, J.M.F. Corrosion aspects of metallic implants-An overview. Mater. Corros. 2008, 59, 855-869. [CrossRef]

132. Omar, S.; Repp, F.; Desimone, P.M.; Weinkamer, R.; Wagermaier, W.; Ceré, S. Sol-gel hybrid coatings with strontium-doped $45 \mathrm{~S} 5$ glass particles for enhancing the performance of stainless steel implants: Electrochemical, bioactive and in vivo response. J. Non-Cryst. Solids 2015, 425, 1-10. [CrossRef]

133. Huang, K.; Cai, S.; Xu, G.; Ye, X.; Dou, Y.; Ren, M. Preparation and characterization of mesoporous $45 S 5$ bioactive glass-ceramic coatings on magnesium alloy for corrosion protection. J. Alloys Compd. 2013, 580, 290-297. [CrossRef]

134. Chen, C.C.; Huang, T.H.; Kao, C.T.; Ding, S.J. Electrochemical study of the in vitro degradation of plasma-sprayed hydroxyapatite/bioactive glass composite coatings after heat treatment. Electrochim. Acta 2004, 50, 1023-1029. [CrossRef]

135. Dou, Y.; Cai, S.; Ye, X.; Xu, G.; Huang, K.; Wang, X. $45 S 5$ bioactive glass-ceramic coated AZ31 magnesium alloy with improved corrosion resistance. Surf. Coat. Technol. 2013, 228, 154-161. [CrossRef]

136. Catauro, M.; Papale, F.; Bollino, F. Coatings of titanium substrates with $\mathrm{xCaO}(1-\mathrm{x}) \mathrm{SiO}_{2}$ sol-gel materials: Characterization, bioactivity and biocompatibility evaluation. Mater. Sci. Eng. C 2016, 58, 846-851. [CrossRef] [PubMed]

137. Gallardo, J.; Galliano, P.; Durán, A. Bioactive and protective sol-gel coatings on metals for orthopaedic prostheses. J. Sol-Gel Sci. Technol. 2001, 21, 65-74. [CrossRef]

138. Hench, L.L.; Hench, L. Bioceramics: From concept to clinic. J. Am. Ceram. Soc. 1991, 74, 1487-1510. [CrossRef]

139. Shahrabi, S.; Hesaraki, S.; Moemeni, S.; Khorami, M. Structural discrepancies and in vitro nanoapatite formation ability of sol-gel derived glasses doped with different bone stimulator ions. Ceram. Int. 2011, 37, 2737-2746. [CrossRef] 
140. Rabiee, S.M.; Nazparvar, N.; Azizian, M.; Vashaee, D.; Tayebi, L. Effect of ion substitution on properties of bioactive glasses: A review. Ceram. Int. 2015, 41, 7241-7251. [CrossRef]

141. Pouraghaei, S.; Moztarzadeh, F.; Nezafati, N.; Rahmanian, F. Synthesis and characterization of silvercontaining sol-gel derived bioactive glass coating. Prot. Met. Phys. Chem. Surf. J. 2016, 52, 285-290. [CrossRef]

142. Catauro, M.; Bollino, F.; Papale, F.; Ciprioti, S.V. Investigation on bioactivity, biocompatibility, thermal behavior and antibacterial properties of calcium silicate glass coatings containing Ag. J. Non-Cryst. Solids 2015, 422, 16-22. [CrossRef]

143. Besra, L.; Liu, M. A review on fundamentals and applications of electrophoretic deposition (EPD). Prog. Mater. Sci. 2007, 52, 1-61. [CrossRef]

144. Boccaccini, A.R.; Keim, S.; Ma, R.; Li, Y.; Zhitomirsky, I. Electrophoretic deposition of biomaterials. J. R. Soc. Interface 2010, 7, S581-S613. [CrossRef] [PubMed]

145. Corni, I.; Ryan, M.P.; Boccaccini, A.R. Electrophoretic deposition: From traditional ceramics to nanotechnology. J. Eur. Ceram. Soc. 2008, 28, 1353-1367. [CrossRef]

146. Hench, L.L. Prosthetic Implant Materials; Academic Press: New York, NY, USA, 1975.

147. Luis, J.; Manrique, E. Processing and characterisation of bioglass ${ }^{\circledR}$ coating on $\mathrm{Ti}_{6} \mathrm{Al}_{4} \mathrm{~V}$ substrates. Supl. Rev. Latinoam. Metal. Mater. 2009, S1,77-90.

148. Farag, M.M.; Ghany, N.A.A.; Ibrahim, A.M.; Abdel-fattah, W.I. Aqueous electrophoretic deposition and corrosion protection of borate glass coatings on $316 \mathrm{~L}$ stainless steel for hard tissue fixation. Surf. Interfaces 2017, 7, 125-133.

149. Abdeltawab, A.A.; Shoeib, M.A.; Mohamed, S.G. Electrophoretic deposition of hydroxyapatite coatings on titanium from dimethylformamide suspensions. Surf. Coat. Technol. 2011, 206, 43-50. [CrossRef]

150. Boccaccini, A.R.; Peters, C.; Roether, J.A.; Eifler, D.; Misra, S.K.; Minay, E.J. Electrophoretic deposition of polyetheretherketone (PEEK) and PEEK/Bioglass ${ }^{\circledR}$ coatings on NiTi shape memory alloy wires. J. Mater. Sci. 2006, 41, 8152-8159. [CrossRef]

151. Kawaguchi, K.; Iijima, M.; Endo, K.; Mizoguchi, I. Electrophoretic deposition as a new bioactive glass coating process for orthodontic stainless steel. Coatings 2017, 7, 199. [CrossRef]

152. Esan, A.; Olusile, A.; Akeredolu, P. Factors Influencing tooth shade selection for completely edentulous patients. J. Contemp. Dent Pract. 2006, 7, 5-11. [CrossRef]

153. Burrow, S.J. Friction and resistance to sliding in orthodontics: A critical review. Am. J. Orthod. Dentofac. Orthop. 2009, 135, 442-447. [CrossRef] [PubMed]

154. Weng, F.; Chen, C.; Yu, H. Research status of laser cladding on titanium and its alloys: A review. Mater. Des. 2014, 58, 412-425. [CrossRef]

155. Val, J.; López-cancelos, R.; Riveiro, A.; Badaoui, A.; Lusquiños, F.; Quintero, F. On the fabrication of bioactive glass implants for bone regeneration by laser assisted rapid prototyping based on laser cladding. Ceram. Int. 2016, 42, 2021-2035. [CrossRef]

156. Comesa, R.; Val, J.; Malot, T.; López-álvarez, M.; Riveiro, A.; Quintero, F. Calcium phosphate grafts produced by rapid prototyping based on laser cladding. J. Eur. Ceram. Soc. 2011, 31, 29-41. [CrossRef]

157. Pou, J.; Boutinguiza, M.; Quintero, F.; Pe, M.; Soto, R.; Leo, B. Main characteristics of calcium phosphate coatings obtained by laser cladding. Appl. Surf. Sci. 2005, 247, 486-492.

158. Krzyzanowski, M.; Bajda, S.; Liu, Y.; Triantaphyllou, A.; Rainforth, W.M.; Glendenning, M. 3D analysis of thermal and stress evolution during laser cladding of bioactive glass coatings. J. Mech. Behav. Biomed. Mater. 2016, 59, 404-417. [CrossRef]

159. Baino, F.; Montealegre, M.A.; Orlygsson, G.; Novajra, G.; Vitale-Brovarone, C. Bioactive glass coatings fabricated by laser cladding on ceramic acetabular cups: A proof-of-concept study. J. Mater. Sci. 2017, 52, 9115-9128. [CrossRef]

160. Karageorgiou, V.; Kaplan, D. Porosity of 3D biomaterial scaffolds and osteogenesis. Biomaterials 2005, 26, 5474-5491. [CrossRef]

161. Bloyer, D.R.; McNaney, J.M.; Cannon, R.M.; Saiz, E.; Tomsia, A.P.; Ritchie, R.O. Stress-corrosion crack growth of Si-Na-K-Mg-Ca-P-O bioactive glasses in simulated human physiological environment. Biomaterials 2007, 28, 4901-4911. [CrossRef]

162. Saiz, E.; Goldman, M.; Gomez-Vega, J.M.; Tomsia, A.P.; Marshall, G.W.; Marshall, S.J. In vitro behavior of silicate glass coatings on $\mathrm{Ti}_{6} \mathrm{Al}_{4} \mathrm{~V}$. Biomaterials 2002, 23, 3749-3756. [CrossRef] 
163. Dorozhkin, S.V. Calcium orthophosphate coatings, films and layers. Prog. Biomater. 2012, 1, 1. [CrossRef] [PubMed]

164. Floroian, L.; Savu, B.; Stanciu, G.; Popescu, A.C.; Sima, F.; Mihailescu, I.N. Nanostructured bioglass thin films synthesized by pulsed laser deposition: CSLM, FTIR investigations and in vitro biotests. Appl. Surf. Sci. 2008, 255, 3056-3062. [CrossRef]

165. Zhao, Y.; Song, M.; Chen, C.; Liu, J. The role of the pressure in pulsed laser deposition of bioactive glass films. J. Non-Cryst. Solids 2008, 354, 4000-4004. [CrossRef]

166. Zhao, Y.; Song, M.; Chen, C.; Liu, J. Effects of the substrate temperature on the bioglass films deposited by pulsed laser. Appl. Surf. Sci. 2008, 254, 6897-6901. [CrossRef]

167. Ma, J.; Wang, C.Z.; Ban, C.L.; Chen, C.Z.; Zhang, H.M. Pulsed laser deposition of magnesium-containing bioactive glass film on porous Ti-6Al-4V substrate pretreated by micro-arc oxidation. Vacuum 2016, 125, 48-55. [CrossRef]

168. Gyorgy, E.; Grigorescu, S.; Socol, G.; Mihailescu, I.N.; Janackovic, D.; Dindune, A. Bioactive glass and hydroxyapatite thin films obtained by pulsed laser deposition. Appl. Surf. Sci. 2007, 253, 7981-7986. [CrossRef]

169. Berbecaru, C.; Alexandru, H.V.; Ianculescu, A.; Popescu, A.; Socol, G.; Sima, F. Bioglass thin films for biomimetic implants. Appl. Surf. Sci. 2009, 255, 5476-5479. [CrossRef]

170. Popescu, A.C.; Sima, F.; Duta, L.; Popescu, C.; Mihailescu, I.N.; Capitanu, D. Biocompatible and bioactive nanostructured glass coatings synthesized by pulsed laser deposition: In vitro biological tests. Appl. Surf. Sci. 2009, 255, 5486-5490. [CrossRef]

171. Wan, R.; Yang, M.; Zhou, Q.; Zhang, Q. Transparent conductive indium zinc oxide films prepared by pulsed plasma deposition. J. Vac. Sci. Technol. A Vac. Surf. Film 2012, 30, 061508. [CrossRef]

172. Huang, Y.; Zhang, Q.; Xi, J.; Ji, Z. Transparent conductive p-type lithium-doped nickel oxide thin films deposited by pulsed plasma deposition. Appl. Surf. Sci. 2012, 258, 7435-7439. [CrossRef]

173. Yang, M.; Pu, H.; Zhou, Q.; Zhang, Q. Transparent p-type conducting K-doped NiO films deposited by pulsed plasma deposition. Thin Solid Films 2012, 520, 5884-5888. [CrossRef]

174. Liguori, A.; Gualandi, C.; Focarete, M.L.; Biscarini, F.; Bianchi, M. The pulsed electron deposition technique for biomedical applications: A review. Coatings 2020, 10, 16. [CrossRef]

175. Bellucci, D.; Bianchi, M.; Graziani, G.; Gambardella, A.; Berni, M.; Cannillo, V. Pulsed electron deposition of nanostructured bioactive glass coatings for biomedical applications. Ceram. Int. 2017, 43, 15862-15867. [CrossRef]

176. Li, P.H.; Chu, P.K. Thin film deposition technologies and processing of biomaterials. In Thin Film Coatings for Biomaterials and Biomedical Applications; Woodhead Publishing Limited: Cambridge, UK, 2016; pp. 3-28.

177. Stuart, B.; Gimeno-Fabra, M.; Segal, J.; Ahmed, I.; Grant, D.M. Preferential sputtering in phosphate glass systems for the processing of bioactive coatings. Thin Solid Films 2015, 589, 534-542. [CrossRef]

178. Berbecaru, C.; Stan, G.E.; Pina, S.; Tulyaganov, D.U.; Ferreira, J.M.F. The bioactivity mechanism of magnetron sputtered bioglass thin films. Appl. Surf. Sci. 2012, 258, 9840-9848. [CrossRef]

179. Stan, G.E.; Pina, S.; Tulyaganov, D.U.; Ferreira, J.M.F.; Pasuk, I.; Morosanu, C.O. Biomineralization capability of adherent bio-glass films prepared by magnetron sputtering. J. Mater. Sci. Mater. Med. 2010, 21, 1047-1055. [CrossRef]

180. Stan, G.E.; Marcov, D.A.; Pasuk, I.; Miculescu, F.; Pina, S.; Tulyaganov, D.U. Bioactive glass thin films deposited by magnetron sputtering technique: The role of working pressure. Appl. Surf. Sci. 2010, 256, 7102-7110. [CrossRef]

181. Stan, G.E.; Morosanu, C.O.; Marcov, D.A.; Pasuk, I.; Miculescu, F.; Reumont, G. Effect of annealing upon the structure and adhesion properties of sputtered bio-glass/titanium coatings. Appl. Surf. Sci. 2009, 255, 9132-9138. [CrossRef]

182. Pasteris, J.D.; Wopenka, B.; Freeman, J.J.; Rogers, K.; Valsami-Jones, E.; Van Der Houwen, J.A.M. Lack of OH in nanocrystalline apatite as a function of degree of atomic order: Implications for bone and biomaterials. Biomaterials 2004, 25, 229-238. [CrossRef]

183. Valerio, P.; Pereira, M.M.; Goes, A.M.; Leite, M.F. The effect of ionic products from bioactive glass dissolution on osteoblast proliferation and collagen production. Biomaterials 2004, 25, 2941-2948. [CrossRef]

184. Stevens, G.J.M.M. Gene activation by bioactive glasses. J. Mater. Sci. Mater. Med. 2006, 17, 997-1002. 
185. Van Oirschot, B.; Meijer, G.J.; Bronkhorst, E.M.; Närhi, T.; Jansen, J.A.; van den Beucken, J.J.J.P. Comparison of different surface modifications for titanium implants installed into the goat iliac crest. Clin. Oral. Implants Res. 2016, 27, e57-e67. [CrossRef] [PubMed]

186. Van Oirschot, B.; Alghamdi, H.S.; Närhi, T.O.; Anil, S.; Al Farraj Aldosari, A.; Van den Beucken, J.J.J.P. In vivo evaluation of bioactive glass-based coatings on dental implants in a dog implantation model. Clin. Oral. Implants Res. 2014, 25, 21-28. [CrossRef] [PubMed]

187. Stuart, B.W.; Gimeno-Fabra, M.; Segal, J.; Ahmed, I.; Grant, D.M. Degradation and characterization of resorbable phosphate-based glass thin-film coatings applied by radio-frequency magnetron sputtering. ACS Appl. Mater. Interfaces 2015, 7, 27362-27372. [CrossRef] [PubMed]

188. Bellucci, D.; Cannillo, V. A novel bioactive glass containing strontium and magnesium with ultra-high crystallization temperature. Mater. Lett. 2018, 213, 67-70. [CrossRef]

189. Bellucci, D.; Salvatori, R.; Anesi, A.; Chiarini, L.; Cannillo, V. SBF assays, direct and indirect cell culture tests to evaluate the biological performance of bioglasses and bioglass-based composites: Three paradigmatic cases. Mater. Sci. Eng. C 2019, 96, 757-764. [CrossRef]

190. Sergi, R.; Bellucci, D.; Salvatori, R.; Maisetta, G.; Batoni, G.; Cannillo, V. Zinc containing bioactive glasses with ultra-high crystallization temperature, good biological performance and antibacterial effects. Mater. Sci. Eng. C 2019, 104, 109910. [CrossRef]

191. Bellucci, D.; Salvatori, R.; Giannatiempo, J.; Anesi, A.; Bortolini, S.; Cannillo, V. A New bioactive glass/collagen hybrid composite for applications in dentistry. Materials 2019, 12, 2097. [CrossRef]

192. Elsayed, H.; Romero, A.R.; Bellucci, D.; Cannillo, V.; Bernardo, E. Advanced open-celled structures from low-temperature sintering of a crystallization-resistant bioactive glass. Materials 2019, 12, 3653. [CrossRef]

193. Bellucci, D.; Veronesi, E.; Strusi, V.; Petrachi, T.; Murgia, A.; Mastrolia, I. Human mesenchymal stem cell combined with a new strontium-enriched bioactive glass: An ex-vivo model for bone regeneration. Materials 2019, 12, 3633. [CrossRef]

194. Bellucci, D.; Veronesi, E.; Dominici, M.; Cannillo, V. On the in vitro biocompatibility testing of bioactive glasses. Materials 2020, 13, 1816. [CrossRef] [PubMed]

195. Bellucci, D.; Cannillo, V.; Sola, A. Calcium and potassium addition to facilitate the sintering of bioactive glasses. Mater. Lett. 2011, 65, 1825-1827. [CrossRef]

196. Sergi, R.; Bellucci, D.; Salvatori, R.; Cannillo, V. Chitosan-Based bioactive glass gauze: Microstructural properties, in vitro bioactivity, and biological tests. Materials 2020, 13, 2819. [CrossRef] [PubMed]

197. Bonnelye, E.; Chabadel, A.; Saltel, F.; Jurdic, P. Dual effect of strontium ranelate: Stimulation of osteoblast differentiation and inhibition of osteoclast formation and resorption in vitro. Bone 2008, 42, 129-138. [CrossRef] [PubMed]

198. Aydin, H. Magnesium supplementation and bone. Magnes. Hum. Heal. Dis. 2013, 57, 149-157.

199. Gorustovich, A.A.; Roether, J.A.; Boccaccini, A.R. Effect of bioactive glasses on angiogenesis: A review of in vitro and in vivo evidences. Tissue Eng. Part B Rev. 2010, 16, 199-207. [CrossRef]

200. Baino, F.; Novajra, G.; Miguez-pacheco, V.; Boccaccini, A.R.; Vitale-brovarone, C. Bioactive glasses: Special applications outside the skeletal system. J. Non-Cryst. Solids 2016, 432, 15-30. [CrossRef]

(C) 2020 by the authors. Licensee MDPI, Basel, Switzerland. This article is an open access article distributed under the terms and conditions of the Creative Commons Attribution (CC BY) license (http://creativecommons.org/licenses/by/4.0/). 